\title{
HIDROQUÍMICA DA BACIA DO RIO PARAUARI - MAUÉS AÇÚ
}

SÉRGIO ROBERTO BULCÃO BRINGEL

Orientador: HENRIQUE BERGAMIN FILHO

Dissertaçāo apresentada à Escola Superior de Agricultura "Luiz de Queiroz" da Universidade de São Paulo, para obtençāo do título de mestre em Energia Nuclear na Agricultura.

PIRACICABA

Estado de São Paulo - Brasil

Agosto - 1980 
. i.

\author{
Aos meus pais, CAMILO e GEMINIANA \\ A minha esposa, GRAÇA \\ As minhas filhas, FABIOLA e KAMILLA \\ Aos meus irmãos, SEBASTIÃO, SANDRA e RAFLEM \\ D E
}


.ii.

A memōria de

JACIMAR FERREIRA DA COSTA 
iii.

\section{AGRADECIMENTOS}

- Ao Prof. Dr. Warwick E. Kerr, ex-Diretor do INPA. pela oportunidade oferecida;

- Ao Prof. Dr. Eneas Salati, Diretor do INPA, pelas proveitosas discussões e sugestões apresentadas;

- Ao Prof. Dr. Admar Cervellini, Diretor do CENA, pelas condições propiciadas;

- Aos Exmos. Srs. Secretários da Educação e Cultura do Estado do Amazonas, Profs. Mario Coelho Amorim, Emina Mustafa e Aldo Gomes da Costa, pela oportunidade e auxílio recebido;

- A Comissão Nacional de Energia Nucleair, pela bolsa concedida;

- Ao Prof. Henrique Bergamin Filho, pela orientação;

- Ao Dr. Nelson de Souza Rodrigues, pelas proveitosas sugestões e pela ajuda indispensável na realização deste trabalho;

- Aos colegas, Drs. Maria de Nazaré Goés Ribeiro, Antonio dos Santos, Umberto de Menezes Santos, Jorge B. Ribeiro, Ubirajara Böechat Lopes, Hugo de Menezes Santos e Henrique F. Carreira, pelas valiosas sugestões apresentadas; 
- Ao Prof. Sфren S. Jörgensen da Royal Veterinary and Agricultural University, Dinamarca, e aos colegas, Drs. Elias zagatto, Francisco Krug, Boaventura Reis, Fernanda Rosias, Neuza Costa Pereira, do CENA, pelo auxílio e sugestões;

- Ao Dr. Alvaro Rangel, pelos serviços de guia durante as nossas viagens como também pelas valiosas informações:

- Aos colegas, Miguel R. de Souza, Demar F. Rodrigues, Antônio A. da Silva, José F. Soares, Antônio Torqua to da Silva, pelas inestimáveis ajudas nas coletas das amostras, e ao Técnico Jose Maria dos Santos, pelo auxílio no preparo das amostras;

- Aos Técnicos de laboratório do CENA, Iolanda Rufini, Angela Foltran e Renato Diniz, pelas valiosas con tribuições na execução das análises;

- E a todos os que, direta ou indiretamente contribui ram para a realização desta pesquisa. 
.$v$.

"Queremos frisar que esta pesquisa foi desenvolvida gragas ao significativo apoio material e financeiro do Instituto Nacional de Pesquisas da Amazônia, à qual expressamos nossos maiores agradecimentos e dedicamos esta página em especial". 


\section{$\bar{I} N \quad N \quad D \quad I \quad C \quad E$}

\section{$\underline{\text { Pägina }}$}

1. RESUMO . . . . . . . . . . . . . . . . . 1

2. INTRODUÇAO . . . . . . . . . . . . . . 2

2.1. Geografia.............. . . 3

2.1.1. Relevo.............. . . 6

2.1.2. Regime de água. . . . . . . . 7

2.2: Clima.................. . . . 9

2.3. Geologia................ 12

2.3.1. Solos................... 13

2.3.2. Areias.......... . . 14

2.3.3. Calcārios............ 14

3. REVISÃO BIBLIOGRAFICA. . . . . . . . . . . . . 17

4. MATERIAL E METODO.............................. 24

4.1. Viagens ................ . . . 24

4.1.2. Localização dos pontos de coletas. . 25

4.2. Métodos............... . . 27

5. RESULTADOS E DISCUSSAO . . . . . . . . . . 29

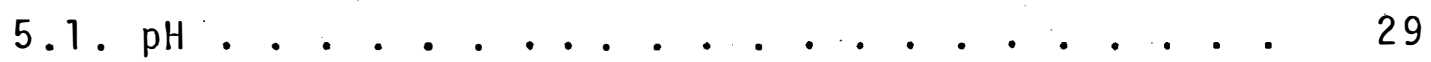

5.2. Cálcio............. . . 32

5.3. Magnésio.. . . . . . . . . . . 36

5.4. Ferro............... . . 4 40 
.vii.

Pāgina

5.5. Cloreto................. . . 45 45

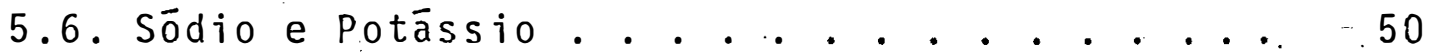

5.7. Cobre, Zinco e Manganês . . . . . . . . 54

6. CONCLUSOES . . . . . . . . . . . . . . 59

7. SUMMARY .............................. 63

8. BIBLIOGRAFIA . . . . . . . . . . . 64 


\section{LISTA DE FIGURAS}

Figura

$\underline{\text { Pägina }}$

1 - Mapa da região, localizando os principais rios, bem como os pontos de coleta.....

2 - Mapa da região Amazónica, indicando os diversos clinnas, segundo a classificação de Köppen

3 - Variação dos valores déĺcálcio ao longo da Bacia estudada............ . . 34

4 - Variação dos valores de Magnésio ao longo da Bacia do Parauari-Maués Açū. . . . . . .

- Variação dos valores de Ferro nos períodos es tudados da Bacia do rio Parauari-Maués Açú. . .

6 - Variação dos valores de cloreto ( $\left.\mathrm{Cl}^{-}\right)$na $\mathrm{Ba}$ cia do Parauari-Maués Açū, nos perĩodos estü dados.................

7 - Variação dos valores de Sódio e Potássio, nos periodos estudados da Bacia do rio Parauari-Maués Açū. . . . . . . . . . . . . 
.ix.

\section{LISTA DE TABELAS}

Tabela

$\underline{\text { Pägina }}$

1 - Dados climatológicos da cidade de Maués-AM no ano de 1974, fornecidos pelo MA-DNPEA-Institu to de Pesquisa Agropecuārio do Norte.....

2 - Valores de pH ao longo da Bacia do rio Parauari-Maués Açū nos quatros perīodos estudados....................

3 - Valores para Cálcio, calculado em $\mu \mathrm{g} .1^{-1}$ para os períodos estudados da Bacia do rio Parauari-Maués Açū. . . . . . . . . . . . .

4 - Valores para o Magnésio nos quatro períodos estudados da Bacia do rio Parauari-Maués Açū, e calculados em $\mu \mathrm{g}^{-1} \mathrm{l}^{-1}$..........

5 - Valores para o Ferro nos períodos estudados da Bacia do Rio Parauari-Maués Açū, calculados em $\mu \mathrm{g} .1^{-1}$. . . . . . . . . . . ...

6 - Valores para o Cloro, na forma de Cloretos $\left(\mathrm{C}^{-}\right)$nos diversos periodos estudados da $\mathrm{Ba}$ cia, e calculados em $\mu \mathrm{g} \cdot \mathrm{l}^{-1} \ldots . . . . .$.

$6 a$ - Valores de cloreto $\left(\mu g .1^{-1}\right)$ em um perfil feito entre os pontos 9.11 e Foz, na amostragem realizado em 22/01 à 10/02/79.....

- Valores de Sódio, para os períodos estudados na Bacia do rio Parauari-Maués Açū, calculados em $\mu \mathrm{g} .1^{-1}$. . . . . . . . . . .

- Valores de Potássio, nos diversos pontos da Bacia do Parauari-Maués Açū, e calculados em $\mu \mathrm{g} \cdot 7^{-1}$. . . . . . . . . . . . . . 
9 - Valores para o Cobre nos diversos trechos da Bacia Parauari-Maués Açú, e calculados em

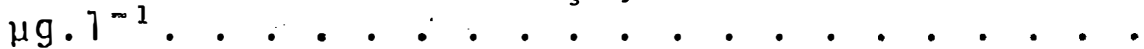

10 - Valores de Zinco, encontrado para os diversos trechos da Bacia Parauari-Maués Açū, e cal culados em $\mu \mathrm{g} .1^{-1}$. . . . . . . . . -

11 - Valores para o Manganês, na Bacia do Parauari-Maués Açū, nos diversos trechos e perīodos estudados, e calculados em $\mu g^{-1} 1^{-1}$. . . 
1. RESUMO

As condições hidroquímicas da bacia do rio Parauari-Maués Açũ. são estudadas a partir das determinações de pH, cálcio, magnésio, ferro, cloreto, sódio, potássio, zinco, cobre e manganês, em diferentes épocas do ano.

Foram realizadas 4 expedições e estabelecidos 16 pontos de coletas de amostras de água em diferentes pontos ao longo do rio principal.

As análises mostram claramente flutuações sazo. nais no rio que constitue o eixo principal da bacia, o Paraua ri-Maués Açü, e em alguns dos seus principais tributários com os Nambi, Amanã e Urupadi. Estas flutuações foram correlacio nadas com os períodos cheio, seco e intermediário, mostrando a importância dessa massa de água, na movimentação de sais ao longo da bacia.

Algumas hipóteses são aventadas na tentativa de explicar algumas anomalias observadas. Sugestões para estudo futuros são apresentados. 
2. INTRODUÇATO

A bacia do rio Parauari-Maués Açū, cobre aprọ ximadamente $25.000 \mathrm{~km}^{2}$ tendo como rio principal, o Parauari com aproximadamente $450 \mathrm{~km}$. Próximo ao paralelo de $3^{\circ} 40^{\prime} \mathrm{s}$ depois da foz do rio Urupadi no local denominado Repartimento, esse rio passa a chamar-șe Maués-Açú até o Paraná do Urariá, onde termina a bacia.

Recebe a bacia, contribuições de vários afluen tes tais como dos rios Nambi, Amanã e Urupadi.

o rio Parauari é um rio de leito estável e de fraca erosão, devido ao fato de sua cabeceira se encontrar nu ma região geológica antiga (pré-cambriano), que é a parte nor te do. Escudo Brasileiro. Por essa mesma razão suas águas transportam pouco material em suspensão. No seu curso médio, atravessa formações geológicas do Paleozóico. Os solos dessa região de um modo geral, são do tipo latosol amarelo, apresen tando um relevo plano levemente ondulado, com escarpas princí 
palmente nas cabeceiras do rio.

Na região dessa bacia afloram ocasionalmente algumas rochas carbonatadas.

o calcārio na região Amazônica é raro, sendo co nhecidas somente algumas jazidas na zona carbonífera do Baixo Amazonas, além dessa pequena quantidade do rio Parauari. 0 cal cário para a região Amazônica, é de importância fundamental, não só para a fabricação de cal e cimento, mas principalmente para a utilização como corretivo para os solos dessa região.

\subsection{Geografia}

A área em estudo está situadá entre os paralelos de $03^{\circ} 00^{\prime}$ e $05^{\circ} 30^{\prime} \mathrm{S}$ e meridianos de $57^{\circ} 00^{\prime}$ a $58^{\circ} 30^{\prime} \mathrm{W} \mathrm{Gr}$. abrangendo terras do município de Maués, Estado do Amazonas.

O município de Maués situa-se na zona fisiogrā fica no Médio Amazonas, com uma ärea de $48.127 \mathrm{~km}^{2}$, 1 imitando-se com os municípios de Barreirinha, Itacoatiara, Nova 01in da do Norte, Borba, Itaituba e Juruti (Figura 1).

Os principais rios que drenam a área, sầ: no centro, correndo do Sul para o Norte, os rios Parauari, Nambi e Amanã. Mais a leste, também correndo do sul ao Norte o rio Urupadi. Mais à oeste, os rios Apoquitáua, Paraconin e Aba- 


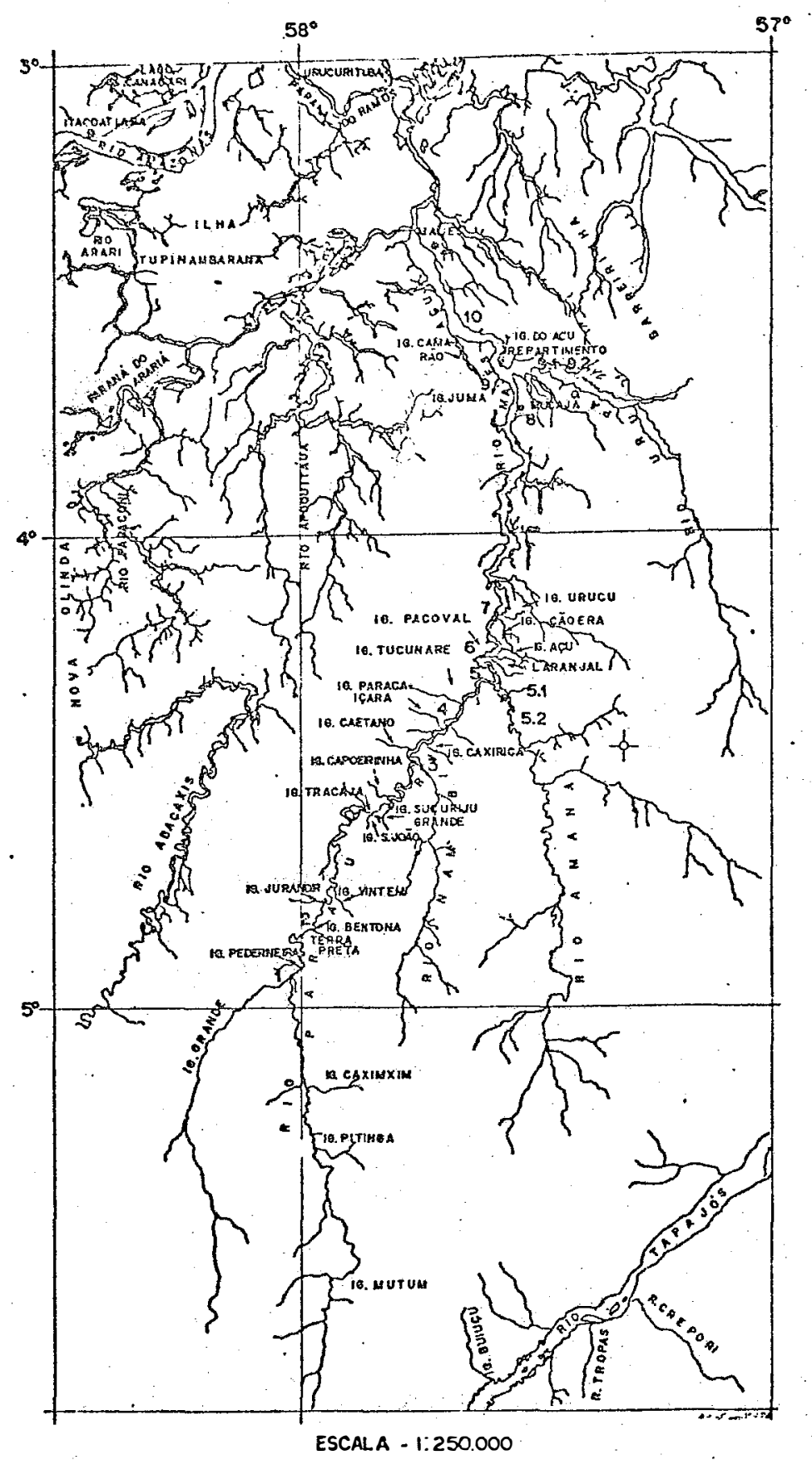

Figura 1 - Mapa da Região, localizando os principais rios, bem como os pontos de coleta. 
caxis. No canto Sudeste, o rio Tapajós e seus afluentes Tropas e Crepori (Figura 1).

Toda a zona situada entre a cidade de Maués e a nascente do rio Parauari, cortada por inúmeros igarapés e rios, é aqui denominada Bacia do Rio Parauari-Maués Açū. Essa região abrange amplas faixas do carbonifero e tem muita importância para o escoamento agrícola, colonização e vida social da região.

Os rios e igarapés que cortam essas terras, são levados pelo Paraná do Urariá ao Paraná do Ramos. Esses rios que vazam no sistema Parauari-Maués Açú são poucos caudalosos, formando nas embocaduras baías de alguns quilômetros de 1argura. Em quase toda sua extensão podem ser observados, na época da vazante, bancos de areias que dificultam a navegação.

A destruição das matas na região da bacia em estudo, ainda é incipiente não tendo consequências graves como em outras āreas da região Amazônica, onde a erosão vem des truindo o manto protetor da mata, arrastando consigo a camada de terra vegetal empobrecendo o solo.

Ao longo do rio Parauri, como na maioria dos rios da Amazônia, observam-se habitações isoladas devido às grandes distâncias. Poucas povoações existem, uma delas em Terra Preta do Calcário dedicada, como diz o nome, à explora 
ção de calcário. No período da seca, esta povoação é abandonada, por falta de transporte. Outros menores, dedicam-se à cultura do guaraná.

A partir do local denominado Repartimento $\left(3^{\circ} 40^{\prime} \mathrm{S}\right.$ e $\left.57^{\circ} 30^{\prime} \mathrm{W}\right)$, onde o rio Parauari recebe o Urupadi, passa a denominar-se Maués-Açū, à margem do qual, à $18 \mathrm{~m}$ acima do nível do mar, fica a cidade de Maués $\left(3^{\circ} 23^{\prime} 32^{\prime \prime} \mathrm{s}\right.$ e $\left.57^{\circ} 43^{\prime} 26^{\prime \prime} \mathrm{W}\right)$.

\subsubsection{Relevo}

A região estudada é similar ao todo da região Amazônica no que diz respeito do relevo.

o relevo na região Amazônica, é caracterizada por extensa planície, que se estende pelas bordas dos planaltos, Guianense ao norte e Brasileiro ao sul. E formada de ro chas sedimentares originadas no Terciārio e Quartenário, de estratificação horizontal, arenosa e argilo-arenosas, consti tuindo o baixo platô, chamado de terra firme, e a planície de inundação (MOURA, 1951).

Os Latossolos Amarelos de textura muito pesada são encontrados em chapadas mais elevadas, nas altitude entre 100 a 160 metros acima do nível do mar. Os Latosolos Amarelos de textura pesada são encontrados nas altitudes de 80 a 
100 metros, e entre 60 a 80 metros, são encontrados os Latosolos de textura média e as Areias Quartzosas Latossólicas. Já - Podzol Hidromórfico e Regosol situa-se nas camadas de 40 a 60 metros e em torno de 40 metros, os Hidromórficos Indiscriminados (IPEAAOC, 1971).

Geralmente, os terrenos que se encontram entre 15 a 50 metros acima dos cursos dos rios, são chamados de "ter ra firme". São representados pir chapadas entremeadas de pequenas colinas e vales estreitos. As terras que são localiza das às margens dos rios e com cerca de poucos metros acima do nível dos rios, e que periodicamente sofrem inundações, são de nominadas de "vārzeas", e seu relevo é plano (IPEAAOC, 1971).

De acordo com a localização, estas várzeas podem receber também o nome de "igapó", havendo controversia com relação a estas denominações (SIOLI, 1950; 1951b e 1956a). São terras com relevo pouco acima do nível normal dos rios, com ve getação típica, de acordo com o período e a altura da subme são, tipos de solo, e também, de acordo com o tipo de águas que as inundam. Nota-se porém uma grande diferença entre a várzea e o igapó, no que diz respeito à fertilidade.

\subsubsection{Regime de água}

o regime de āgua na bacia do rio Parauari-Maués 
Açū e seus afluentes, obedece em linhas gerais, a distribui ção anual de inverno e verao ou estação seca e chuvosa, conforme denominação regiona1.

A diferença entre o nível mínimo de àgua no ve rão e seu nível máximo no inverno, é de mais ou menos 10 metros, valor estimado por observação das marcas que as äguas deixam nas árvores.

A profundidade redia do rio Parauari da boca do rio Nambi até a primeira cachoeira (cachoeira do Tambor) no período seco é de aproximadamente 1 metro. Em muitos 1o cais são encontrados "baixios" que são lugares com profundida de até menos de meio metro e tambēm "poços", que são locais bastante fundos, verdadeiros buracos no leito do rio.

A largura do rio Parauari, sofre pequenas variações com a enchente e a vazante devido à inclinação dos barrancos marginais. São ravinas ingremes que variam entre 2 a 8 metros de a1tura.

Mesmo quando o barranco fica completamente submerso, a vegetação ciliar limita perfeitamente as margens do rio. Tanto no verão como no inverno a largura média do rio Parauari é quase constante e varia entre 40 e 100 metros.

o leito do rio Parauari, nos trechos onde a observação é possíve1, é constituído de areia fina, pedregu1hos e seixos rolados, conforme a correnteza da água. As pe- 
dras e rochas típicas de cachoeira são geralmente revestidas parcialmente de vegetàção aquātica.

As praias de areias são muito raras, e somente encontradas na época da seca.

Jà no rio Maués-Açū, hā grande praias que surgem principalmente no período seco do ano, dando a este rio, um aspecto alegre, embelezando a paisagem.

\subsection{C1ima}

Como em toda a Amazônia, esta região também é quente e úmida com duas estações distintas: as chuvas que co. meçam em dezembro e se estendem até julho, e a estação menos chuvosa que vai de agosto até novembro.

Torna-se difícil detalhar o clima dessa região, devido a falta de estações meteorológicas, pois em toda essa área, somente a cidade de Maués possue um posto de observações.

Na Tabela 1 são apresentados alguns dados meteorológicos da cidade de Maués do ano de 1971.

Na Figura 2 estão representados alguns tipos climáticos da Região Amazônica, segundo a classificação de Köppem. A ārea de nosso interesse está situada entre os para 


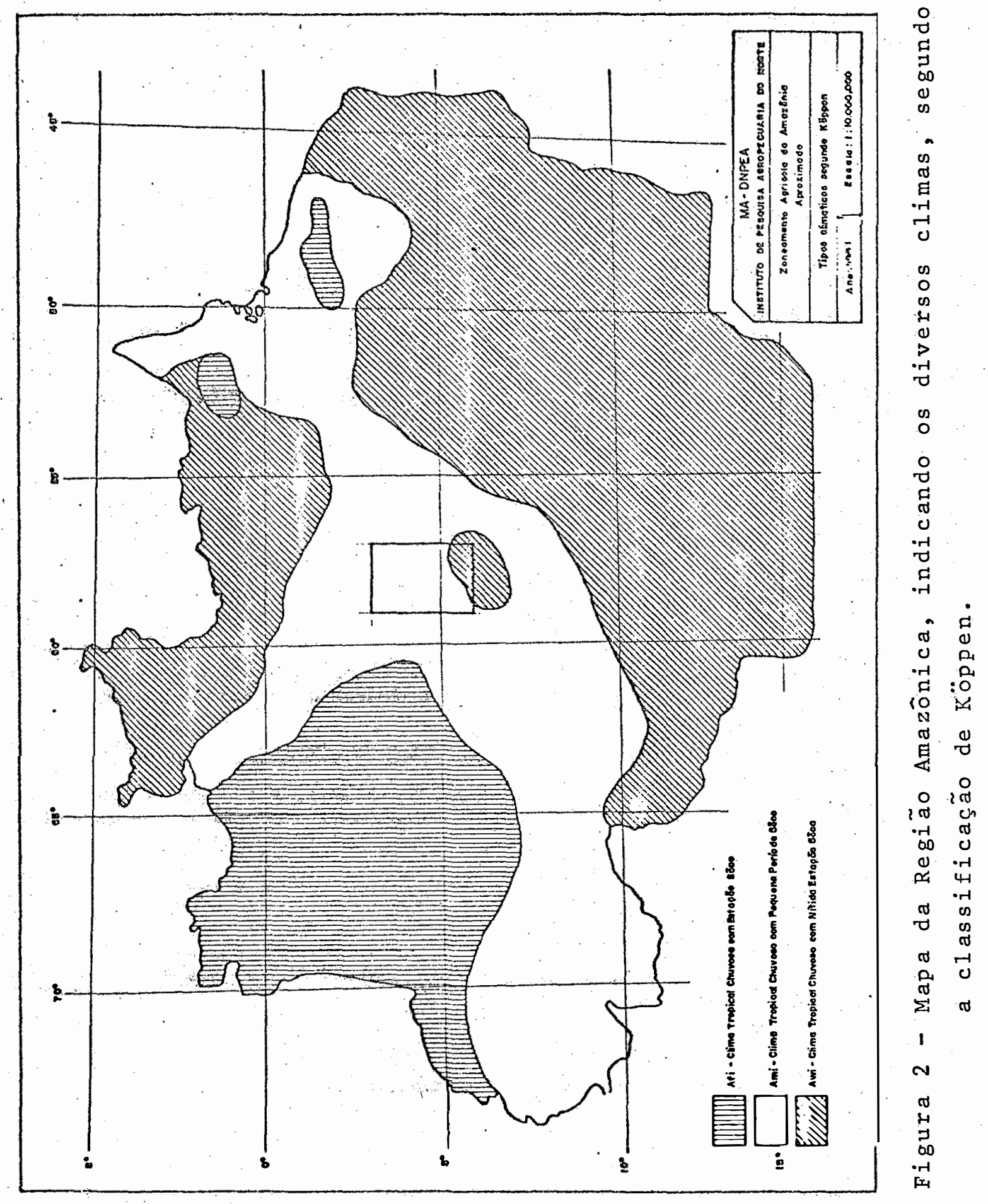


Tabela 1 - Dados climatológicos da cidade de Maués-Am no ano de 1971, fornecidos pelo MADNPEA-Inst. de Pesquisa Agropecuärio do Norte.

\begin{tabular}{|c|c|c|c|c|c|}
\hline \multirow{2}{*}{ MESES } & \multicolumn{3}{|c|}{ TEMPERATURA DO AR EM ${ }^{\circ} \mathrm{C}$} & \multirow{2}{*}{$\begin{array}{l}\text { UMIDADE } \\
\text { RELAT IVA } \\
\text { EM \% }\end{array}$} & \multirow{2}{*}{$\begin{array}{c}\text { PRECI I ITACA AO } \\
\text { PLUVIOMETRI CA } \\
\text { EM MM }\end{array}$} \\
\hline & MAXIMA & MINIMAS & MEDIA & & \\
\hline JAN & 30,5 & 21,7 & 26,1 & 85 & 410 \\
\hline FEV & 30,4 & 21,6 & 26,0 & 90 & 463 \\
\hline MAR & 30,4 & 21,3 & 25,8 & 87 & 396 \\
\hline$A B R$ & 29,9 & 20,8 & 25,4 & 85 & 472 \\
\hline MAI & 30,6 & 21,1 & 25,8 & 85 & 286 \\
\hline JUN & 30,8 & 21,2 & 26,0 & 85 & 117 \\
\hline JUL & 31,2 & 21,0 & 26,1 & 84 & 212 \\
\hline AGO & 32,3 & 21,4 & 26,8 & 78 & 58 \\
\hline SET & 32,1 & 20,8 & 26,4 & 75 & 100 \\
\hline OUT & 33,1 & 21,4 & 27,2 & 80 & 46 \\
\hline NOV & 33,0 & 21,8 & 27,4 & 80 & 88 \\
\hline DEZ & 32,1 & 31,8 & 27,0 & 80 & 139 \\
\hline ANO & 31,4 & 21,3 & 26,3 & 82 & 2.696 \\
\hline
\end{tabular}


lelos de $3^{\circ} 00^{\prime}$ a $6^{\circ} 00^{\prime} \mathrm{S}$ e meridianos de $57^{\circ} 00^{\prime}$ a $59^{\circ} 00^{\prime} \mathrm{W}$ Gr. 2.3. Geologia

Segundo..OLIVEIRA e LEONARDOS (1943), a princi pal feição das camadas terceārias na bacia do rio Maués-Açú (bem como no rio Abacaxis e outros tanto a Leste como a Oeste) é a predominância das argilas vermelho-alaranjadas, ora arenosas, ora micáceas, em bancos maciços e alguma estratifi c ação nítida.

Essas argilas aparecem numa faixa ao norte e noutra ao sul do rio Amazonas, mais ou menos paralelas ao eixo do vale, numa extensão de värias centenas de quilômetros.

Em outros lugares, fora da bacia do rio Maués-Açū, a Série das Barreiras é·constituída também por are nito de textura muito grosseira com cimento ferruginoso; argi las variegadas, muito plásticas, sem quartzo; arenitos com cí mento caolínico e de textura mais ou menos grosseira e mais ou menos friáveis; e arenito de textura média, cimento caolínico ou não, geralmente manchado de vermelho e branco, consolidado pelo ferro.

A bacia do Parauari-Maués Açú, atravessa as formações do Cristalino, Devoliano, Carbonífero e Permiano, que se situam no alto Parauar, enquanto que o curso médio 
atravessa as formações Terciärias, e no seu curso baixo (rio Maués-Açū), atravessa as formações do Quartenário.

\subsubsection{Solos}

Na região em estudo, os solos tem sua origem a partir de material de rochas sedimentares, possivelmente vin das do Terciário e Quartenário.

os solos do Terciārio são representados pela Série das Barreiras, do período Plioceno, sendo um dos mais extensos depōsitos terciários do mundo, situado em terra firme (OLIVEIRA e LEONARDOS, 1943). A Série das Barreiras,é cons tituída de um arenito pürura avermelhado claro, cimentado com caulinita e folhelho caulinitico e caulinita maciça mosqueada. Este arenito quando intemperizado, forma normalmente os solos argilosos, argilo-arenosos como os latossolos de classe texturais diferentes (SAKAMOTO, 1957).

Do Quartenário, podemos encontrar, o Pleistoce no e o Holoceno ou Atual. O Pleistoceno, é geralmente formado pela deposição de sedimentos constituídos de areia, argila de caulim e silte (OLIVEIRA e LEONARDOS, 1943). Estes sedimentos são encontrados também na região do Parauari que quando associados à matéria orgânica na superfície dão origem aos solos Podzol Hidromórfico e Regossol. 
o Holoceno, é encontrado nas margens dos cursos de ägua e nas áreas que periodicamențe sofrem inundações, e é constituído de sedimentos compostos de areia fina, silte e argila, de coloração escura devido a matéria orgânica dando origem aos solos Hidromórficos Indiscriminados (OLIVEIRA e LEONARDOS, 1943)。

\subsubsection{Areias}

$$
\text { Grandes extensoes ao longo do rio Parauari }
$$
acham-se cobertas por depósitos de areia, que se assentam sobre as formações originais.

São dunas deslocadas para o leito do rio, havendo uma separação dos grãos de areia mais grossos dos mais finos, pela ação das águas e dos ventos.

$$
\text { Geralmente são areias alvas e, na superfície, }
$$
há pequena mistura com matéria orgânica.

\subsubsection{Calcários}

As jazidas de calcārio formam desde lentes de porte médio até grandes lentes, que podem ser consideradas ca madas. Esses depósitos, quando são de calcário puro, com me- 
nos de $2 \%$ de MgO, quase sempre são limitados por faixas mais ou menos dolomitizadas no contato com a rocha encaixante, onde surgem impurezas constituídas por silicatos de metamorfis mo .

Nos gnaisses, também sao encontrados lentes in teiramente formadas de calcário dolomítico, cristalino, compacto, de granulação média e fină, de cor branca ou dolomitos duros de granulação grossa. Os primeiros contam cerca de 16 a $18 \%$ de MgO e os ü1timos de 19 a $21 \%$ de MgO。

Na região Amazônica, são conhecidos vārios depósitos de calcário, sendo os mais importantes os da formação Itaituba, que aflora naquela localidade, à margem do rio Tapajós, no Pará, o do rio Parauari, no Estado do Amazonas, e o de Monte Alegre, à margem do rio Amazonas, no Pará ( $A B R E U$, 1973). o afloramento que ocorre no Parauari, è um calcário duro, que em parte passà à arenito calcífero, altamente fossi Iifero e de cor escura, composto de conchas quebradas e cimentadas, calcificadas posteriormente.

o calcário que aflora no trecho compreendido entre o igarapé da Benta Grande e o igarapé do Vintém, è um pouco mais mole e fica em parte, imerso nas águas.

Na região em estudo, jā está sendo explorado o afloramento próximo à Terra Preta do Calcário, que pela literatura (ABREU, 1973) possivelmente pertença a Formação 
Itaituba. Até onde foi possível observar, extende-se entre os igarapés da Pederneira e o Vintém, ocọrendo ainda pequenos afloramentos em outros trechos do rio.

Os calcários da Formação Itaituba, são de origem marinha, de cor cinza claro, lenticulares, bem endurecidos, levemente dolomitizadas, apresentando alto e variado teor fossilifero (DAEMON e CONTREIRAS, 1971). No Parauari, MOURA (1932) encontrou o diabásio, sobre o calcário. 
.17.

\section{REVISÃO BIBLIOGRÄFICA}

$$
\text { ALBUQUERQUE (192̈́) estudou a geologia e geogra }
$$

fia dos rios: Urubū, Uatumã, Jatapū, Capū-Capú, mostrando que a formação terciāria se mostra horizontal no baixo curso destes rios nas proximidades do Amazonas, apresentando-se incli nadas no alto Urubū.

Verificou também que por baixo da formação ter ciāria são encontradas as formações do Paleozóico, pouco movi mentadas, com apenas sensível inclinação, geralmente para o su 1 .

Na bacia do Trombetas, encontrou rochas terciārias constituindo uma capa sobre as formações paleozóicas. Essa capa, constitui geralmente as terras altas, com caracteres que se afastam do tipo comum das rochas terciārias do barranco do Amazonas.

No rio Jatapū, a pouco mais de $2 \mathrm{~km}$ da foz do rio Capü-Capú encontrou bancos de calcārio carcomido, deixan- 
do salientes e bem conservados abundantes fósseis silicificados. Junto ao calcário acha-se um folheto cinzento e manchado de preto também ricamente fossilífero, e no qual se acham intercalado os bancos de calcários.

0 autor considera essa fauna igual à da Pedra de Barco (Terra Preta do Calcário) no rio Parauari, imputando a sua origem por isso, bem como à formação correspondente, ao carbonifero superior.

SIOLI (1949) dā uma visão geral da situação geo grä́fica ’ das condições gerais do rio Cupari, descrevendo a topografia, geologia, principalmente do ponto de vista minera 1 ógico.

Estudou ainda, a faixa do carbonífero do Baixo Amazonas, principalmente os afloramentos que ocorrem no Cu pari. Discute ainda o pH, cālcio, magnésio, alumínio, e etc. dessa bacia, fazendo comparações com outras regiões geográfi cas. Prova com isso, uma relação entre a composição química das äguas e a qualidade do solo das cabeceiras, condicionadas pela Geologia e Mineralogia.

SIOLI (1956a) estudou os corpos de água do rio Arapiuns típico da região do Terciärio, Plioceno, série das Barreiras, do Baixo Amazonas. Fez uma generalização histórica e geográfica, geológica, climática e do regime de água nes sa região dando uma idéia nítida das condições da mesma. 
o resultado desse estudo foi a comprovação de uma pobreza em sais dissolvidos e de uma acidez elevada dessa äguas. Reconheceu que certos fenômenos químicos especiais são relacionados com os processos que ocorrem nos solos sob as con dições dos trópicos.

SIOLI (1956 b) descreveu a geologia, geografia e o clima da região que representa a zona dos rios de "água preta". Verificou o fato de que as florestas de terra firme, não alagáveis, produzem em ambas as margens do alto rio Negro, igarapés: diferentes, a curta distância um do outro: igarapés de àgua cristalina igarapés de "água preta" de cor marrom aver me 1 hado.

$$
\text { SIOLI (1957a) estudou o pH das águas naturais }
$$
de rios e ilgarapés da região Amazônica, notando que essas äguas possuem composição e propriedades físico-químicas relacionadas, até certo grau, com a natureza geológica e a composição mineráógica do solo e do subsolo.

Observou também que muitas vezes, as propriedades físico-químicas das águas, são mais ou menos uniformes numa zona geológica inteira, o que é característica da mesma.

SIOLI (1957c) verificou que águas mais ou me nos neutras ou mais ricas em cālcio aparecem a lém das faixas do carbonífero da baixa Amazônia, também numa parte da Zona Bragantina, ao leste de Belém (Pa.), na zona da Formação Pira 
rabas, do Mioceno, que consiste de depósitos marinhos com camadas de calcário de pequena espessura. Como a extensão da Formação Pirabas era desconhecida especialmente na direção sul, Sioli tentou limitar essa região geológica por meio dos valores de pH dos igarapés.

SIOLI e KLINGE (1962) fizeram considerações so bre a química e as cargas de suspensão nos diversos tipos de ägua, para demonstrar a existêfifia da relação entre as àguas e os solos da Amazônia. Afirmam que os diferentes tipos de agua podem ser explicadas por diferença nas condições edáficas nas respectivas regiões de cabeceiras.

ACKERMANN (1962) fez um retrospecto da fisiografia da Região Bragantina, descrevendo suas formações geogräficas estudando a Formação Pirabas e relatando ainda outras ocorrências que se relacionam com essa formação. Estudou, ạinda, as águas, os solos, bem como os depósitos de conchas. existentes.

SIOLI (1965) discrimina os três tipos clässicos de rios (rios de "água branca", "águas claras" e "águas pretas"), descrevendo os fatores físicos-quimicos das zonas de cabeceiras.

Discute os problemas que surgem quando se pretende entrar em detalhe sobre a tipologia dos rios Amazônicos. Essa tipologia baseia-se somente em fenômenos facilmente veri 
ficáveis; entretanto não possui, em seu conteúdo, uma paralela explicação causal dos fatores genéticos dos aludidos tipos de rios.

Acrescenta ainda, que em certos casos pode ha ver mudança temporária de tipo - em ciclos anuais ou mesmo não periōdicos, dentro de dias ou mesmo horas - de maneira que uma classificação num noutro tipo torna-se ilusōria.

\begin{abstract}
Alguns exemplos são citados, explicando as a 1terações - atē mesmos as alterações extremas - por intermédio das influências do ambiente do rio, condicionado sobre tudo por fenômenos climáticos, as vezes em combinação com certas condições pedológicas.
\end{abstract}

SIOLI (1957b e 1968a) partindo da histöria geo lógica da règião Amazônica descreveu o clima (temperatura, quan tidade e distribuição da chuva) e os corpos de águas (tipos, morfologia e quimismo das àguas correntes) da mesma.

Afirmou ainda, que em conjunto com esses fatores, o relevo, e a cobertura vegetal determinam o caräter des sa unidade de paisagem. E, concluiu pela pobreza dos solos através da pureza das āguas. Afirmou que a selva amazônica vive mais "em cima" do solo do que "do solo".

Discutiu ainda, os diferentes tipos de vegeta ção como sendo ligados a diferentes tipos de solos, inclusive 
a economia d'água. dos mesmos (floresta alta e campo - 1atoso-

los - águas claras; caatinga e campina - podsolos - aguas pre tas).

Ainda SIOLI (1968b) afirmou que na Amazônia Bra sileira, as relações entre a química das águas naturais (águas freáticas e águas correntes) e a geologia das āreas de influên cia sobre as mesmas são notavelmente nítidas.

Verificou que os maciços do arqueano ao Norte e ao Sul do Amazonas, produzem águas que são quimicamente bas tante pobres e que possuem valores de pH bem baixos. Disse ain da que mais pobre e mais ācidas $\sim$ sao as āguas nas zonas da Sé-rie das Barreiras e- da Formação Pará, ambas de origem do PIio

ceno - Pleistoceno, enquanto que no Oeste da Amazônia, na zo-na da Formação Pebas, ocorre águas mais ricas e menos àci das.

Constatou que as āguas dessa área geológica são bem diferentes daquelas das faixas do carbonífero nas quais se encontram depósitos de calcārio e de gipsita e ocorrências de diabase. Tais àguas são geralmente mais ricas em íons inorgânicos e possuem valores de pH mais alto.

ALMEIDA e SOUZA (1972) estudaram uma ärea res trita do município de Maués, mais precisamente a ärea da Cam panhia Antartica Paulista, a fim de conhecerem dados pedológicos e de fertilidade desse, solos.

Os autores afirmam que os solos dessa área pos 
suem uma fertilidade muito baixa, e teor elevado de alumínio, chegando, mesmo, à atoxidez.

\section{BRINKMANN e SANTOS (1973) trabalhando em região}

terciāria da Amazônia, próximo a Manaus, afirmam que a princi pal fonte de cálcio encontrada nessa região, deve ser proveniente da lavagem da copa, das folhas e do caule, pela chuva, e até um certo ponto, pela dissolução de produtos metabólicos de macro e micro organismos.

Encontraram traços de cālcio dee chuvas, igara pes e rios. Afirmam que o cālcio pode ser encontrado como ele mento circulante num ambiente fechado. E que e um modo gera 1 ós teores de cālcio nas àguas naturais da região Terciāria Amazônica são extremamente baixos. 
4. MATERIAL E METODO

4.1. Viagens

Foram realizadas quatro viagens à bacia do rio Parauari-Maués Açú. A primeira, foi entre os dias 3 a 17 de fevereiro de 1976 coincidindo com o auge da enchente do rio, estando já o "inverno" bastante intenso com chuvas frequentes.

A segunda foi realizada no mês de dezembro de 1976, entre os dias 15 a 30, quando o sistema Parauari-Maués Açú estava com o nível mínimo de água, no verão, com chuvas esparsas e de pouca duração.

A terceira, entre os dias 26 de dezembro de 1977 a 6 de janeiro de 1978, quando as āguas da bacia já tí nham começado a subir, aproximadamente no meio da enchente, e as chuvas do inverno jä eram notadas.

A quarta, efetuou-se no periodo de 22 de janeiro a 10 de fevereiro de 1979. Nesta viagem as águas da 
bacia, tinham um comportamento quase idêntico ao que foi obser vado durante a terceira viagem, porém, com um nível maior de àguas e chuvas bastante frequentes.

Devido a falta de recursos, não foi possível um maior número de viagens. Seria de tóda conveniência, a rea liłaçäo de um estudo mais completo, em continuação desse traba 1 ho.

\subsubsection{Localização dos pontos de coletas}

0 ponto de coleta de amostras de água ao longo da bacia do rio Parauari-Maués Açū, estão indicados na Figu ra 1 .

Dentro o sistema fluvial em estudo, considera mos o rio Parauari, com、o principa'1, seguido do Maués-Açú. Co mo tributārios, os rios Nambi e Amanã para o Parauari e o Uru padi para o Maués-Açū.

Seguindo o curso do sistema fluvial desde sua nascente até a foz, o primeiro ponto de coleta (I) está localizado em frente ao igarapé da Pederneira (próximo a Terra Preta do Calcārio); $20 \mathrm{~km}$ abaixo, ou seja, próximo ao igarapé da Benta Grande, foi coletada a amostra de nümero 2. Devi do dificuldades de acesso a este igarapé, só foi possível a 
coleta de uma amostra, tomada $2 \mathrm{~km}$ acima da embocadura, que $\vec{e}$ o ponto $(2.1)$.

0 ponto de número 3 , estä 1ocalizado a $100 \mathrm{~km}$ do igarapé da Benta Grande, ou seja, na foz do rio Nambi. E $15 \mathrm{~km}$ abaixo, perto do igarapé do Paracaiçara, foi coletada a amostra de número 4. 0 ponto 5, foi localizada na foz do rio Amanã, distante. $30 \mathrm{~km}$ daquele igärapé.

No rio Amanã, foram coletadas duas amostras, sendo uma a $10 \mathrm{~km}$ do ponto 5, próximo ao local denominado San to Antonio, (amostra de número 5.2) e a outra, no Varre Vento à $5 \mathrm{~km}$ da f̀oz do mesmo rio, (ponto de número 5.1).

A amostra de número 6, foi feita no Laranjal, que dista $15 \mathrm{~km}$ da foz do rio Amañ̃. No igarapé do Cão Era, à $20 \mathrm{~km}$ do Laranjal estä localizado o ponto 7., e a $80 \mathrm{~km}$, des te 1ocal, ou mais precisamente na Vila Mucajá, foi estabeleci do o ponto 8. O ponto de número 9, fica no Repartimento, ou seja, na confluência do rio Parauari com o Urupadi, distante $10 \mathrm{~km} \mathrm{da} \mathrm{Vila} \mathrm{Mucajá.}$

No rio Urupadi, foram efetuadas duas coletas, sendo que a amostra 9.2, foi coletada em frente ao igarapé da Pedreira, à $10 \mathrm{~km}$ do Repartimento e a de número 9.1', defron te ao igarapé do Traira, a $5 \mathrm{~km}$ do igarapé da Pedreira. 
próximo ao igarapé do Camarão, (ponto 10), e finalmente, na ci. dade de Maués, no ponto 11 , que dista $20 \mathrm{~km}$ do igarapé do Camarão .

\subsection{Métodos}

As amostras de āgua, foram tomadas na superfí cie, e acondicionadas em frasco de polietileno.

As determinações foram realizadas pelos seguintes métodos e aparelhagens:

1. $\mathrm{pH}$ determinação potenciométrica utilizando-se aparelho tipo WTW pH 390, com eletrodo de vidro e calibrado com soluções padrões de pH 4.00 e 6.90 .

2. Cá1cio, Magnésio, Ferro, Manganês, Zinco e Cobre foram determinados por Espectrometria de Absorção Atômica, utilizando-se o aparelho da Perkin E1mer, mode1o 306, equipado com um registrador da Radiometer Copenhagen REC 61 Servograph.

3. Sódio e Potássio foram determinados em Espectrometria de Emissão, utilizando-se o aparelho da Perkin E1mer mode1o 306 , equipa 
do com um registrador da Radiometer Copenhagen REC 61 Servograph.

4. Cloro como Cloreto ( $\mathrm{CH}^{-}$) foi determinado por volumetria, segundo método do IBP HANDBOOK, 1971, n? 8 . 


\section{RESULTADOS E DISCUSSÃO}

\section{1. $\mathrm{pH}$}

$$
0 \text { pH das águas da região é de origem natural, }
$$
proveniente de ácido carbônico dissolvido, seja da atmosfera, ou mais provavelmente do que se encontra na zona da infiltração do solo produzido pela respiração dos organismos vivos.

Neste caso, o pH da água depende do conteúdo de ácido carbônico e da quantidade de outros minerais dissolvidos .

Entre os constituintes básicos, encontra-se o carbonato de cálcio, que condiciona o $\mathrm{pH}$, pois ao reagir com - $\mathrm{CO}_{2}$ dissolvido forma o bicarbonato de cálcio solúvel, produ zindo um sistema tampão.

Os valores de $\dot{p H}$, mostram uma relação evidente, entre o terreno e o meio ambiente. E de se esperar, que a zo na carbonífera forneça às águas uma maior quantidade de subs- 
tâncias tampão. Como podemos observar na Tabela 2 , que apresenta os valores de pH, medidos nas diferentes localidades da bacia Parauari-Maués Açū, nos períodos estudados, as águas dessa região são menos ácidas, que as estudadas por SIOLI (1956a, $1956 b$ e 1957a).

Podemos verificar, que a região em estudo, devido a existência de calcário, pr̈oduz äguas quase neutras, enquanto que as outras da Amazấ,ia Central, dão origem à àguas ácidas. Isto pode ser atribuído ao sistema tampão (bicarbona to/gás carbônico) que contudo não impede que o pH sofra algumas variações sazonais.

Estas variações, são devidas ao aumento ou diminuição do volume de água dos rios. As águas de precipitação com um total de $2.696 \mathrm{~mm}^{-1} o^{-1}$, ao diluirem as substâncias tampão provenientes do solo e subsolo da região, afetam o equilibrio do efeito, tampão. Os fatores que podem ainda provocar essas mudanças de pH são de um lado, maior dissolução de bases do substrato e do outro, uma maior quantidade de $\mathrm{CO}_{2}$ dissolvido, trazida pela chuva. Além disso, deve ser con siderada a atividade biológica do sistema. 


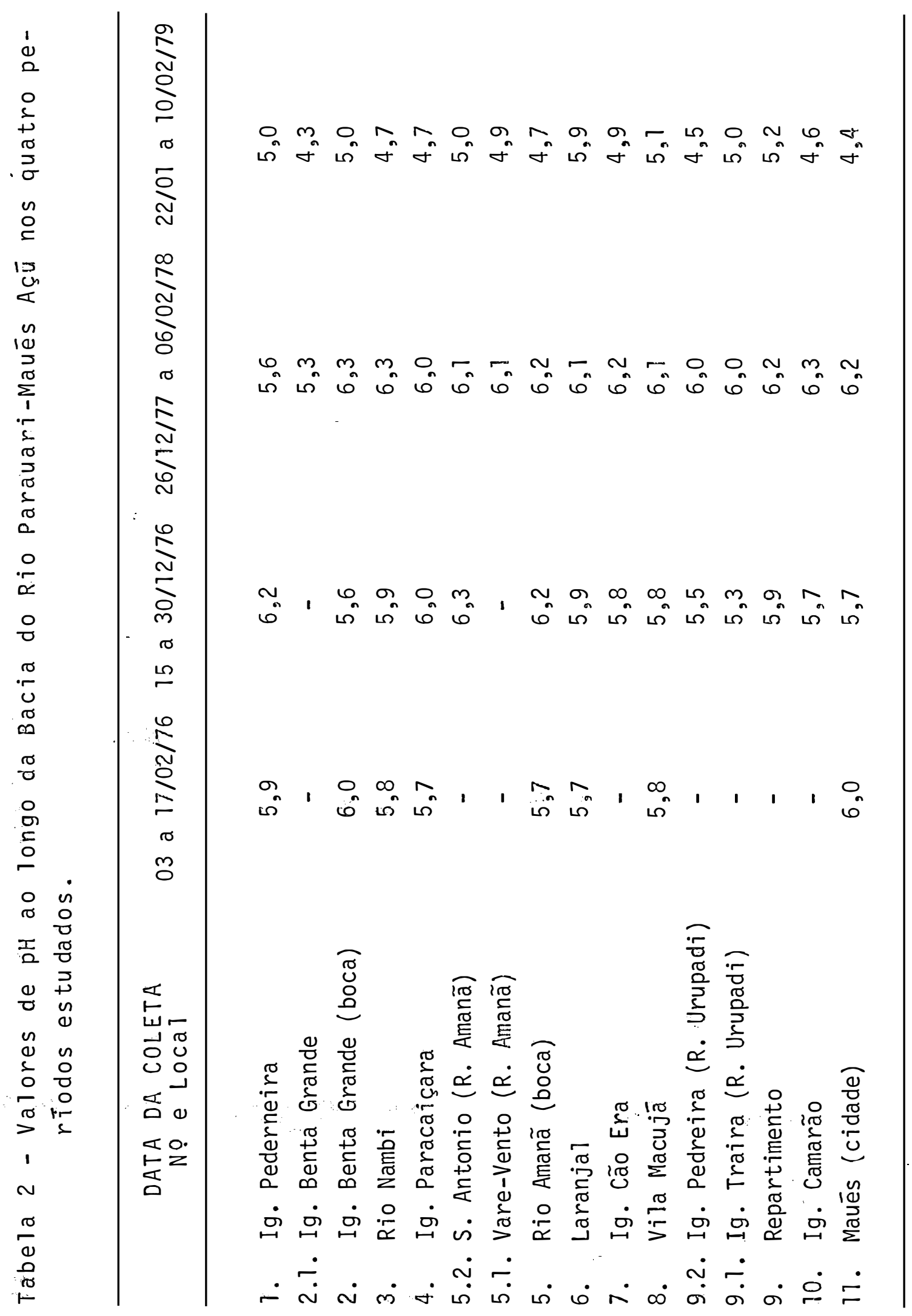


5.2. Càlcio

$$
\text { SIOLI em } 1956 b \text { e BRINKMANN e SANTOS em } 1972
$$

afirmam que o conteūdo de cālcio e magnésio nas regiões Terciārias da Amazônia Central, são relativamente baixos; estes íons geralmente seriam provenientes da lavagem das folhas, cau le e tronco pelas águas de chuva.

Ainda SIOLI (1956a; 1956b; 1957a e 1968b), encontrou valores muito baixos desses íons nas vārias regiões por ele estudadas. SANTOS et ali $i$ (1978), trabalhando em região de terra firme da Amazônia Central, também encontraram valores muito baixos para esses $\mathfrak{i} o n s$.

A região em estudo situada em Zona Carbonífera, pode ser considerada uma exceção como também foi observado por SIOLI (1949) para a região do rio Cupari.

o calcário que aflora em vários pontos do rio Parauari, enriquece essas águas com sais de cálcio, fazendo com que ocorra uma variação deste íon nos diversos pontos estudados da bacia.

Podemos observar na Tabela 3 e Figura 3, a variação dos teores de cálcio, nos períodos estudados. No perío do cheio, foi observado um teor de $180 \mu g \cdot 1^{-1}$ entre o igarapé da Pederneira e o Laranjal; sofrendo um acréscimo da concentração para $270 \mu g \cdot 1^{-1}$ na Vila Mucajá e alcançando $360 \mu g \cdot 1^{-1}$ 


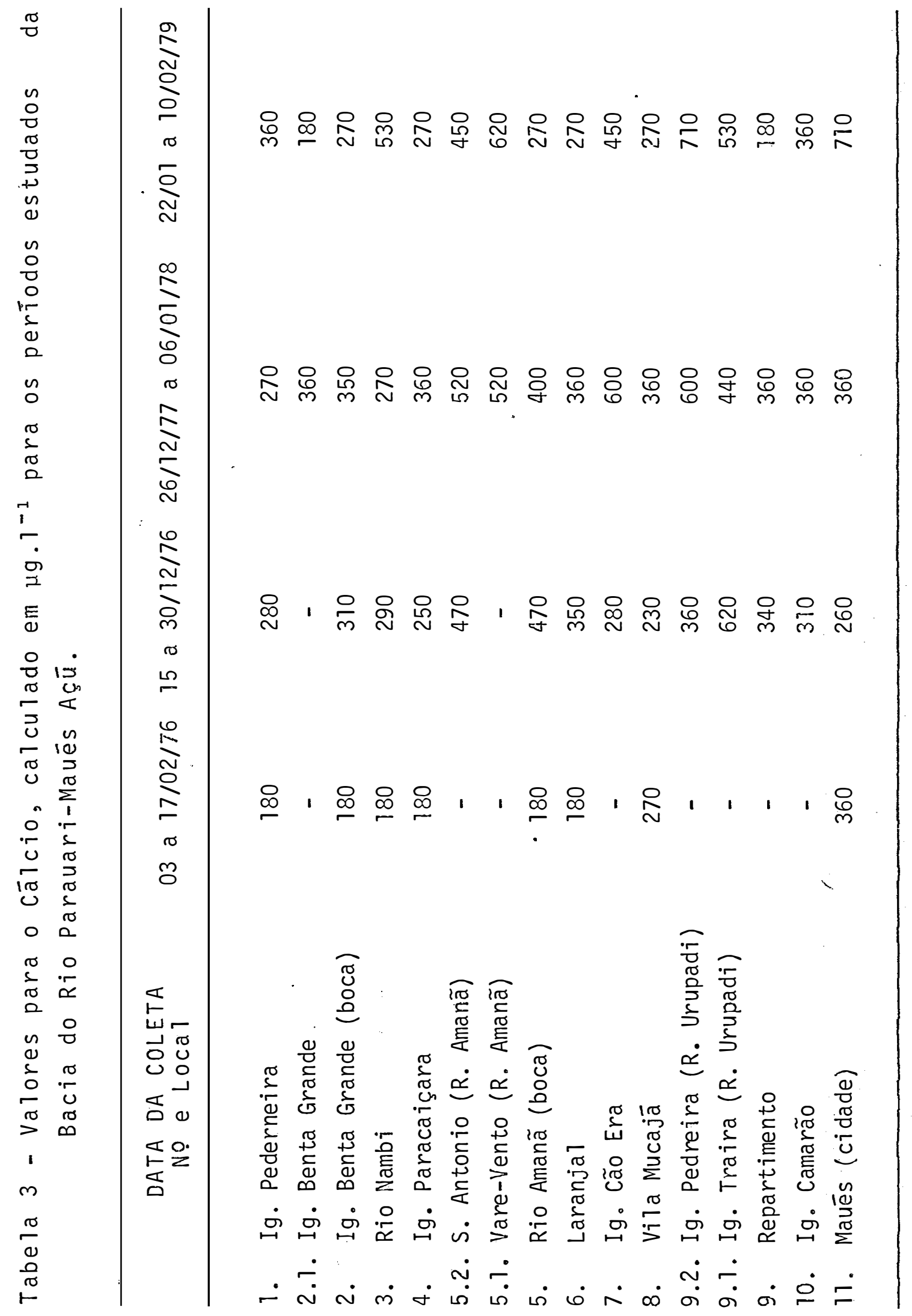




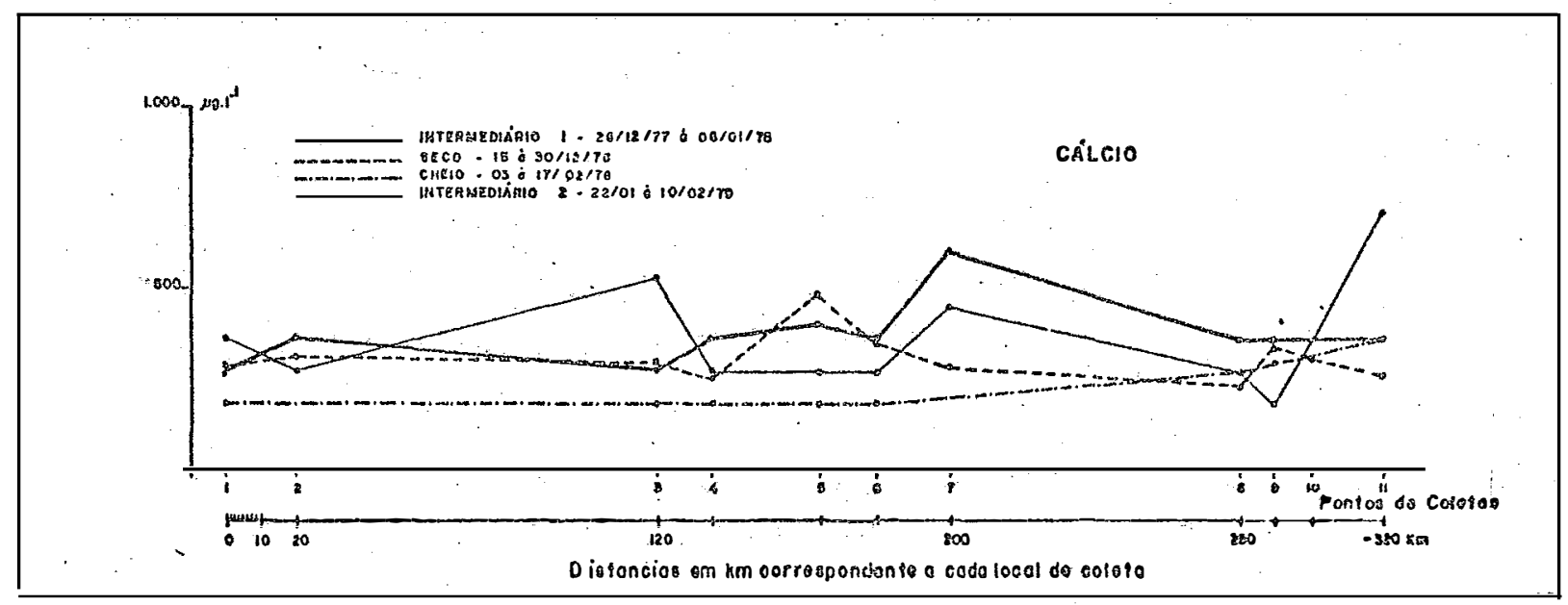

Figura 3 - Variação dos valores de Cálcio ao longo da Bacia estudada. 
na cidade de Maués próximo da fóz provavelmente, isto pode ser atribuído, a uma maior dissolução das partículas de $\mathrm{CaCO}_{3}$ sedimentadas no leito da bacia, favorecida ainda pelo volume de água e pela própria correnteza. Outra hipótese, não confirmada, seria a ocorrência de calcário no leito, nessa região.

Com a bacia no seu mais baixo nível, verifica-se uma variação desse elemento no Sistema Parauari-Maués Açü. Isso deverse provavelmente, às chuvas que caem na região, e que trazem parte das partículas do calcário que é explorado na área. Apesar de ocorrer uma diluição ao longo da bacia da ordem de $20 \mu g \cdot 1^{-1}$, observam-se sensíveis oscilações no teor de cálcio.

o rio Amanã (ponto 5.2) com alto teor desse íon faz com que a concentração no rio principal, o Parauari, seja aumentada, como observa-se no ponto 5. No rio Urupadi (pontos 9.2 e 9.1) a alta concentração, contribui novamente para a elevação do teor de cálcio, decaindo pouco a pouco como observado nos pontos 10 e 11 , ou seja, no igarapé do Camarão e nà cidade de Maués.

Quando os rios da bacia, começam a aumentar de volume, as águas das fortes chuvas que caem na região, ainda encontramos calcário disponível, como mostra a Tabela $\in$ Figu ra 3. Entretanto, observa-se que o rio Amanã (pontos 5.2 e 5.1), apresenta concentrações elevadas, contribuindo para que 
o rio principal acuse uma elevação na sua concentração, como mostra o ponto 5 da bacia.

O rio Urupadi (pontos 9.2 e 9.1.), apresentando uma concentração bastante elevada de cälcio, não influencia o rio principal, isto provavelmente porque a bacia, a partir deste trecho, é aumentada em largura como em volume de āgua, tendendò à uma estabilização dos teores de cálcio.

\subsection{Magnésio}

Na Tabela e Figura 4, encontramos os valores de magnésio para os períodos estudados, mostrando também suas variações ao longo da bacia. Observa-se, no período cheio, que o maior teor encontrado, foi na boca do rio $\Lambda m a n a ̃$ (portc 5), com um valor de $970 \mu g \cdot 1^{-1}$, enquanto que a amostra do ponto 11 na cidade de Maués, apresentou a menor concentração desse ion, $\left(430 \mu g \cdot 1^{-1}\right)$, mostrando uma tendência a diminuir a concentração à medida que se aproxima da foz.

Para o período seco, a concentração de magnê sio não sofre variações acentuadas, observando-se a mesma tendência de diminuir a concentração com a proximidade da foz. Os maiores valores encontrados neste período foram no igarapé da Pederneira e na Vila Mucajà (340 $\left.\mu g \cdot 1^{-1}\right)$. 


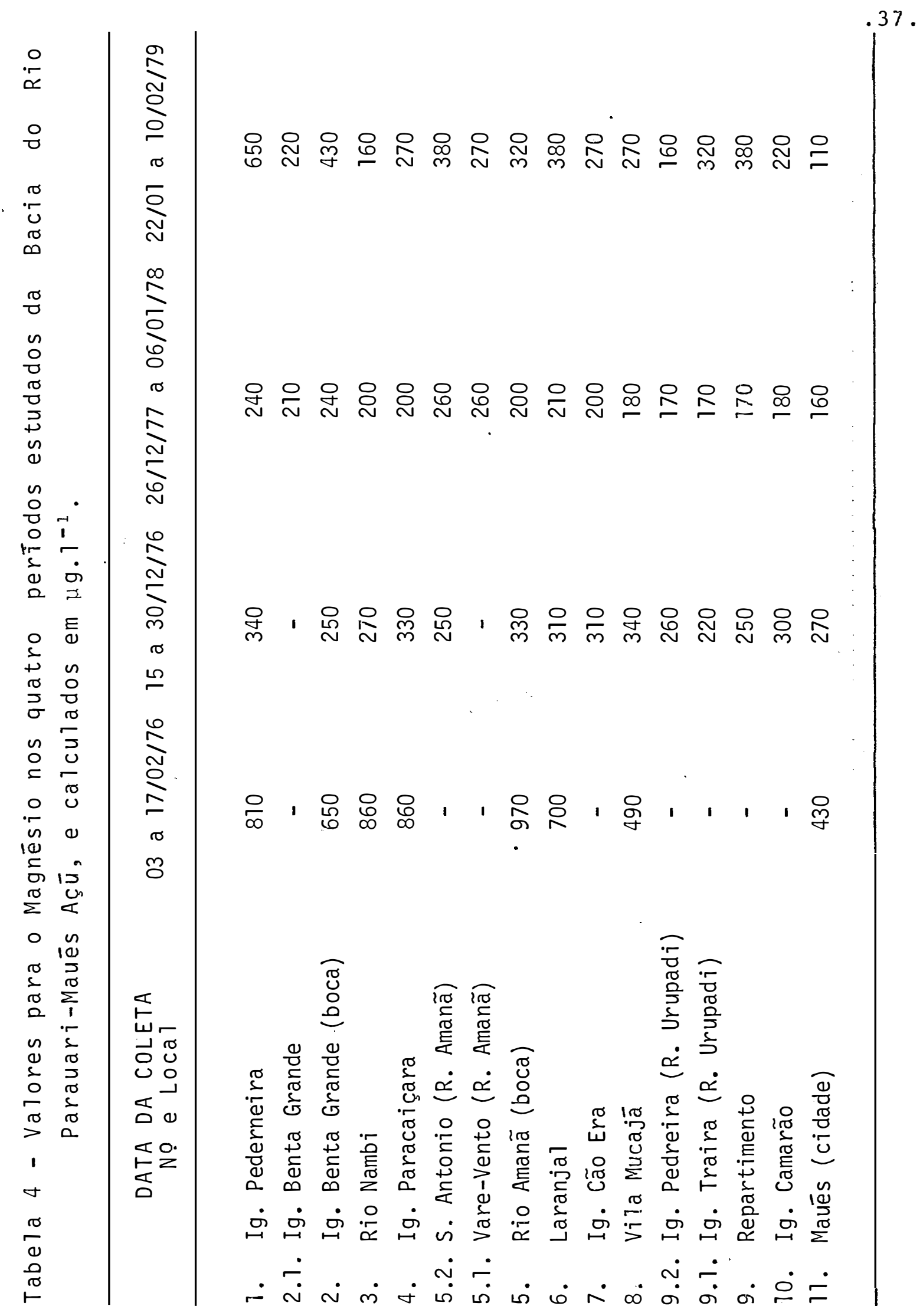




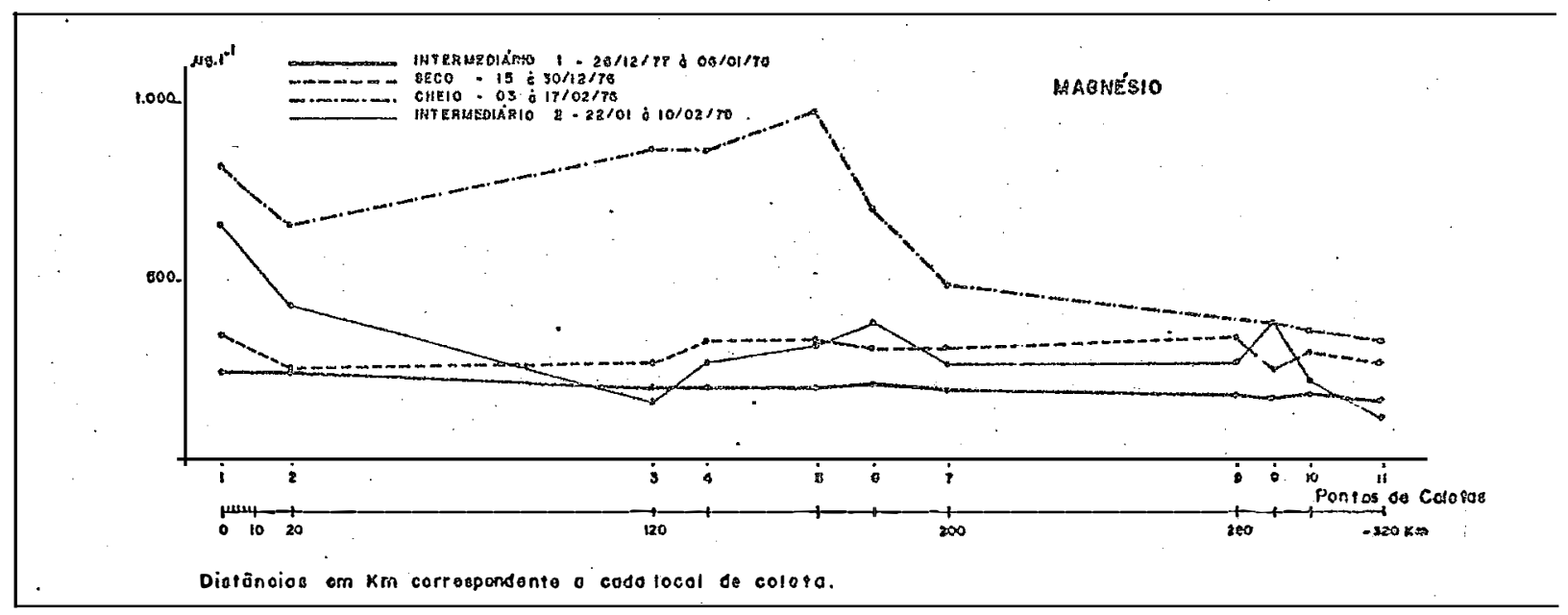

Figura 4 - Variação dos valores de Magnésio ao longo da Bacia do Parauari-Maués-Açú. 
No rio Amanã (ponto 5.2 da Tabela 4 e Figura 4), com $250 \mu g \cdot 1^{-1}$ de magnésio, notamos que o rio princi pal não sofre modificações na sua concentração, (330 $\left.\mu g^{-1} 1^{-1}\right)$ encontrado tanto no igarapé do Paracaiçara (ponto 4), como na boca do rio Amanã (ponto 5). Porém, sua concentração é aumentada logo em seguida, na Vila Mucajá (340 $\left.\mu g \cdot 1^{-1}\right)$.

No rio Urupadi (pontos 9.2 e 9.1 ) os valoreencontrados, são de $260 \mu \mathrm{g} \cdot 1^{-1}$ e $220 \mu \mathrm{g} \cdot 1^{-1}$, respectivamente, concorrendo para o teor de magnésio no rio principal seja diminuỉdo, pois sua concentração cai no ponto 9 , (250 $\left.\mu g \cdot 1^{-1}\right)$.

Há um pequeno aumento na concentração do rio principal quando este recebe o igarapé Camarão (300 $\left.\mu g \cdot 1^{-1}\right)$, voltando a partir desse ponto a mesma tendência anterior.

Quando as águas da bacia começam a aumentar de volume, as concentrações sofrem menores variações notando-se entretanto, a mesma tendência de a concentração diminuir com a aproximação da foz.

Com a continuação da subida d'água, a bacia do rio Paruari-Maués Açū, tende a aumentar seu teor de magnēsio (Tabela e Figura 4). A maior concentração verificada nes sa época (22/01 a 10/02/79), foi no igarapé da Pederneira $\left(650 \mu g \cdot 1^{-1}\right)$. Daí em diante, a bacia passa a apresentar cer tas flutuações, em consequência das äguas que o rio principal recebe de seus tributários, ocasionando um aumento ou dimi- 
nuição na concentração de magnésio, dependendo do teor com que esses afluentes contribuem.

Observamos, que nessa amostragem (22/01 a 10/02/79), o ponto de coleta que está situado em frente a cidade de Maués, o de número 11 , foi encontrada uma concentração excepcio nalmente baixa $\left(110 \mu g \cdot 1^{-1}\right)$, valor esse, possivelmente ocasionada por uma forte chuva durante a coleta, provocando uma diluição na superfície do rio. .

\subsection{Ferro}

SIOLI (1949), para a região do rio Cupari,obser va que "A quantidadé de ferro na āgua depende do terreno e do meio ambiente. Parece ser proveniente do subsolo e das ca madas superiores, mostrando somente variações insignificantes e não determinadas, em correlação com as estações do ano".

Segundo ANON (1972b), as águas de precipitação fornecem ao sistema (rio Negro) $2 \mathrm{~kg}$ de Fe ha. ano ${ }^{-1}$.

o ferro encontrado nas águas da bacia do Parauari-Maués Açū, é também, provaveìmente, introduzido no meio ambiente pelas lavagens que sofrem o solo devido a alta pluviosidade da região $\left(2.696 \mathrm{~mm}\right.$. ano $\left.{ }^{-1}\right)$.

os valores de ferro na ärea em estudo (Tabela 
e Figura 5), mostram que no período cheio, os teores de ferro sofrem modificações, provavelmente devido as alterações (oxi-re dução) causadas no meio ambienté de drenagem. Essas variações estão relacionadas com as precipitações pluviométricas, que contribuem para a elevação do volume d'água, provocando ainda uma dissolução das partículas lixiviadas. As alterações observadas ao longo da bacia, possivelmente, podem ainda ser atribuídas as contribuições dosafluentes. Isso é demonstrado pela alta concentração verificada no igarapé da Benta Gran de $\left(860 \mu g \cdot 1^{-1}\right)$.

No período seco, as variações no teor de ferro não são acentuadas, e, outra vez, é na foz do igarapé da Benta Grande (ponto 2) que se apresenta a maior concentração $\left(530 \mu \mathrm{g} \cdot \mathrm{I}^{-1}\right)$. No rio Urupadi (pontos 9.2 e 9.1 da Tabela e Figura 5), com $310 \mu \mathrm{g} \cdot 1^{-1}$ e $160 \mu \mathrm{g} \cdot 1^{-1}$, respectivamente, também ocorre um pequeno aumento da concentração.

Para o período intermediārio, a bacia apresen ta teores mais baixos, com ligeiras alterações no rio Nambi e no igarapé do Paracaiçara (200 $\mu g / 1)$.

As condições climāticas do ano $1975 / 76$, que dé terminaram o início do ciclo da cheia de 1976, foram bastantes anormais, em relação aos anos anteriores e consequentes. Em 1976 tivemos a ocorrência da 2a maior enchente do século, $(29,61 \mathrm{~m}$ acima do nível do mar), $8 \mathrm{~cm}$ mais baixa que a ocorri da em 1953. 


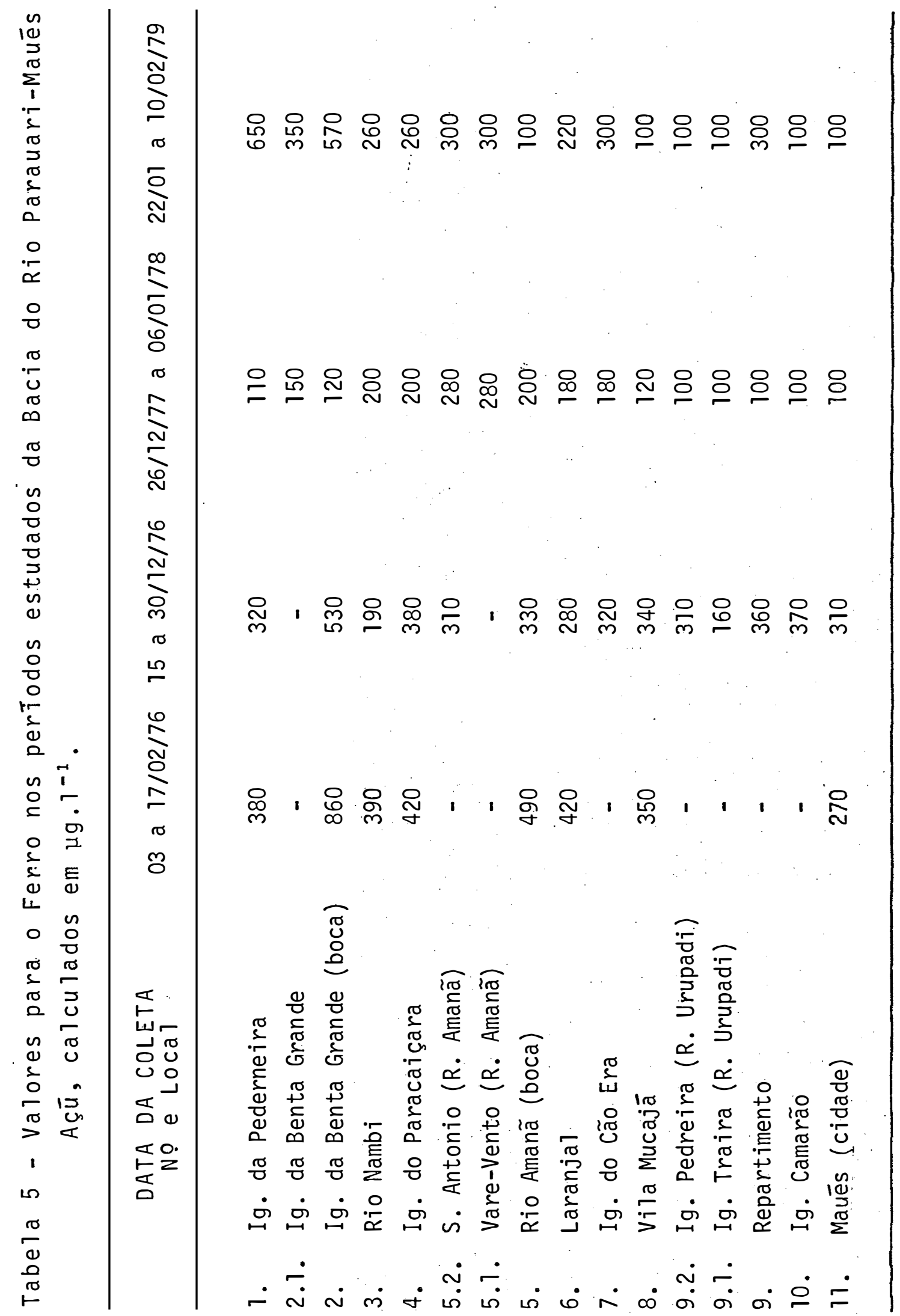




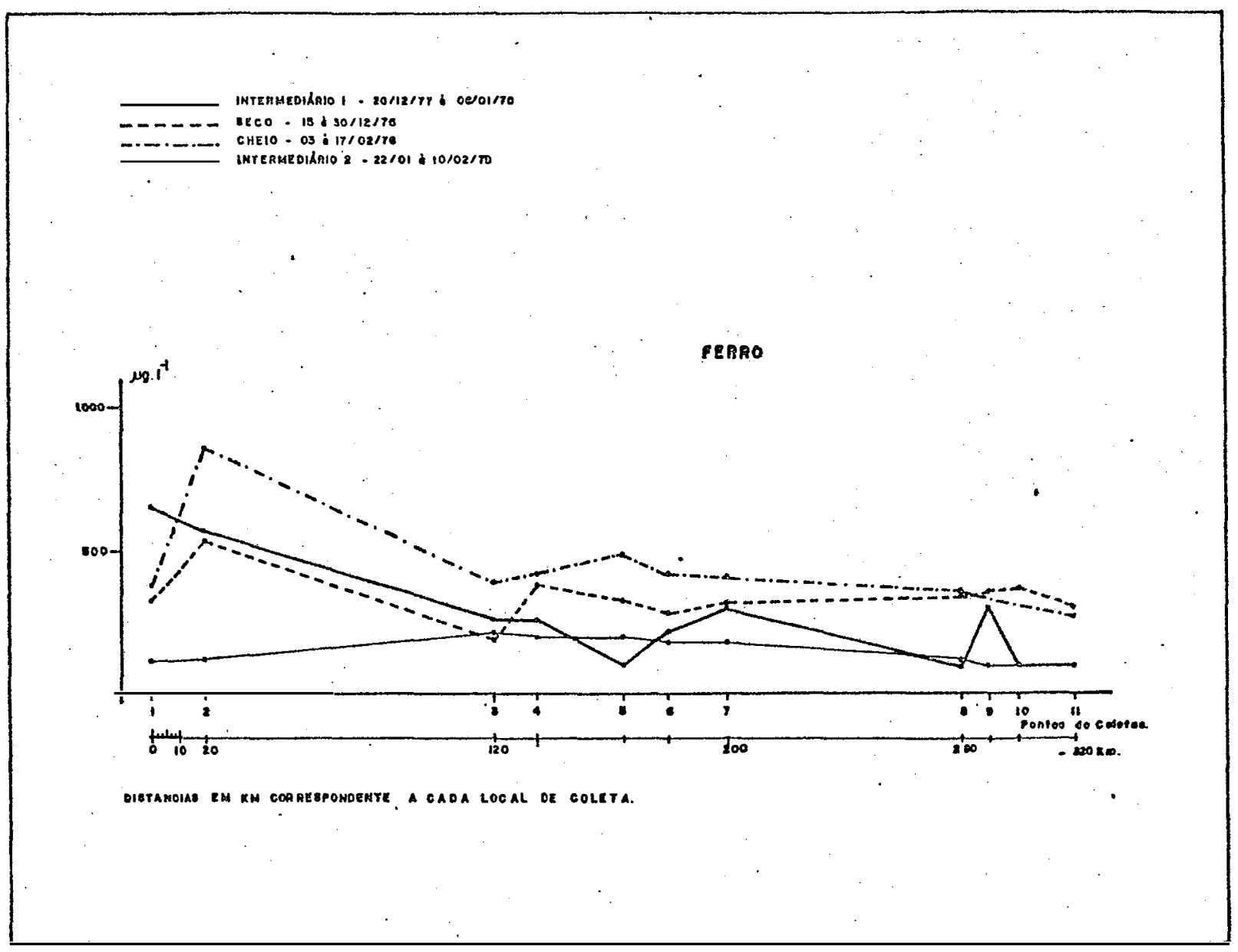

Figura 5 - Variação dos valores de Ferro nos períodos estuda dos da Bacia do rio Parauari-Maués-Açū. 
A apreciaçao devida deste fenômeno é de fundamental importância para a interpretação de dados hidroquími$\cos$.

Com a anormalidade climätica de $1975 / 76$, prat $\underline{i}$ camente não houve um período de estiagem definido,tendo o iní cio das chuvas ocorrido mais cedo, que o normal (dezembro/ja neiro) não permitindo uma vazante completa, como também, não se dèfinindo o período de menor lixiviação correspondente à estiagem. Assim quando foi feita a primeira amostragem (fevereiro/76) jā havia ocorrido a resposta das lixiviações provocadas pelas chuvas. Segundo LEVISON (1974), as respostas ocorrem aproximadamente dois meses após o início da estação.

o fenômeno parece muito evidente pois os valores para o ferro em 1976, foram de $860 \mu g \cdot 1^{-1}$ no igarapé da Benta Grande (rio Parauari) e de $570 \mu g \cdot 1^{-1}$ em 1979, pratica mente no mesmo mês. Isto mostra que em 1976 já tînhamos uma resposta enquanto que em 1979, provavelmente, o fenômeno ainda não havia ocorrido.

Algumas anomalias merecem citação: a que foi observada no igarapé da Benta Grande (ponto 2), nos períodos de 13 a $17 / 2$ e de 15 a $30 / 12$ em 1976, e a observada em 22/1 a $10 / 2$ de 1979 no ponto 9, Repartimento.

Verificou-se também o já observado por ANON (1972a) que a concentração dos componentes dissolvidos nas 
águas fluviais diferem notavelmente em períodos comparáveis de diferentes anos.

\subsection{Cloreto}

o cloreto é introduzido no sistema de drenagem, pelas águas das chuvas pela remineralização das substâncias das florestas, e ainda à possível ocorrência de depósitos de salgema na região.

Em anālise feita nas águas de chuva, no período (15 a 30/12/76), foi constatado uma concentração de $740 \mu \mathrm{g} \cdot 1^{-1}$. Sabe-se porém, que esta concentração é muito va riável não só de época para época, como mesmo entre chuvas cónsecutivas, tornando-se difícil uma conclusão sobre a verdadeira influência destas águas.

Seria mesmo, de toda a conveniência, que estü dos posteriores detalhassem estas variações nas diferentes épocas do ano para se chegar a uma definitiva conclusão sobre sua influência nas àguas da região, uma vez que ANON (1972b) observa uma nítida diferença nas concentrações dos elementos na estação seca para a chuvosa, sendo que no período seco, as concentrações são mais elevadas, porém com a continuidade das precipitações, os íons tendem a diminuir sua concentração nas àguas de chuva. 
Na Tabela e Figura 6 , observamos as variações de $\mathrm{Cl}^{-}$, nos períodos e trechos da bacia estudado. Nelas nota mos que na época seca, a bacia Parauari-Maués Açū, sofre sensíveis modificações na sua concentração. A estação seca e quente, e de esparsas chuvas, contribue de modo geral, para uma maior concentração salina.

No período cheio, a concentração de $\mathrm{Cl}^{-}$varia de $640 \mu \mathrm{g} \cdot 1^{-1}$ do igarapé da Pederneira, para $700 \mu \mathrm{g} \cdot 1^{-1}$ na cidade de Maués, dando uma elevação de $60 \mu g \cdot 1^{-1}$. Esta alte ração, pode ser atribuída principalmente ao arrastamento de sais de cloro, devido a remineralização de restos vegetais pe las àguas de chuva.

No período intermediário, também observamos al gumas alterações provavelmente devidas a uma lavagem mais com pleta das superfícies ciliares com restos vegetais.

Estas alterações são mais acentuadas, com a continuidade das chuvas, como mostram os valores encontrados no período (22/01 a 10/02/79).

A fim de verificar a existência de variações verticais, foi feito um perfil entre o Repartimento e a cidade de Maués (pontos 9 e 11) e um outro na foz da bacia.

Os resultados são apresentados na Tabela 6 a. Esses dados levam a crer que existe uma corrente diferencial 


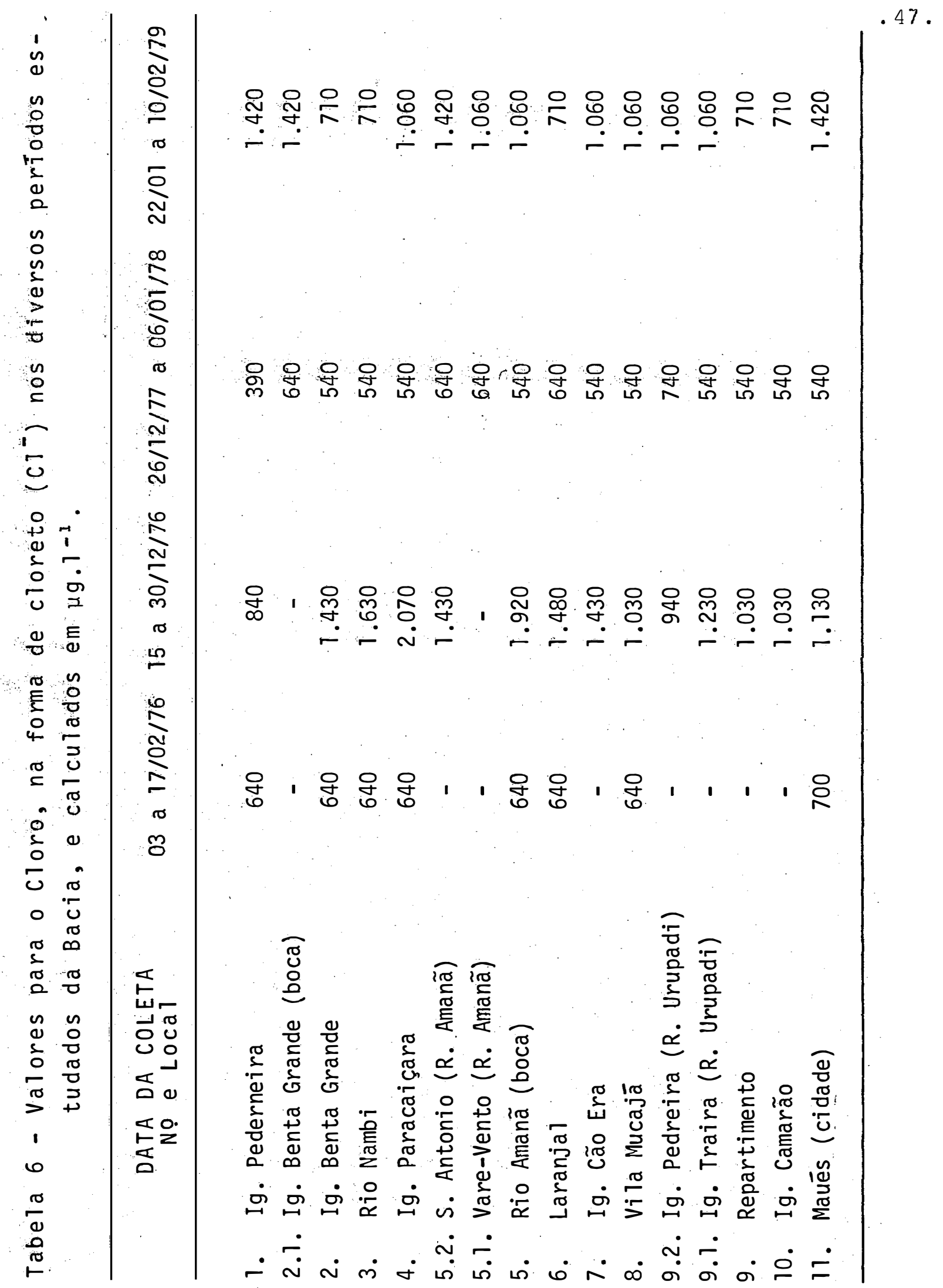


.48 .

Tabela 6a - Valores de Cloretos $\left(\mu \mathrm{g} .1^{-1}\right)$ em um perfil, feito entre os pontos 9,11 e Foz, na amostragem reali zada em 22/01 à 10/02/79.

\begin{tabular}{lrrrrr} 
PROF. (m) & & & & \\
\hline $\begin{array}{c}\text { Nọ DO PONTO } \\
\text { DE COLETA }\end{array}$ & 0 & 5 & 7 & 10 & 22 \\
\hline & & & & & \\
9 & 710 & - & 1.770 & - & - \\
11 & 1.420 & 1.060 & - & 1.770 & 2.130 \\
Foz & 1.770 & - & - & 1.770 & - \\
\hline
\end{tabular}




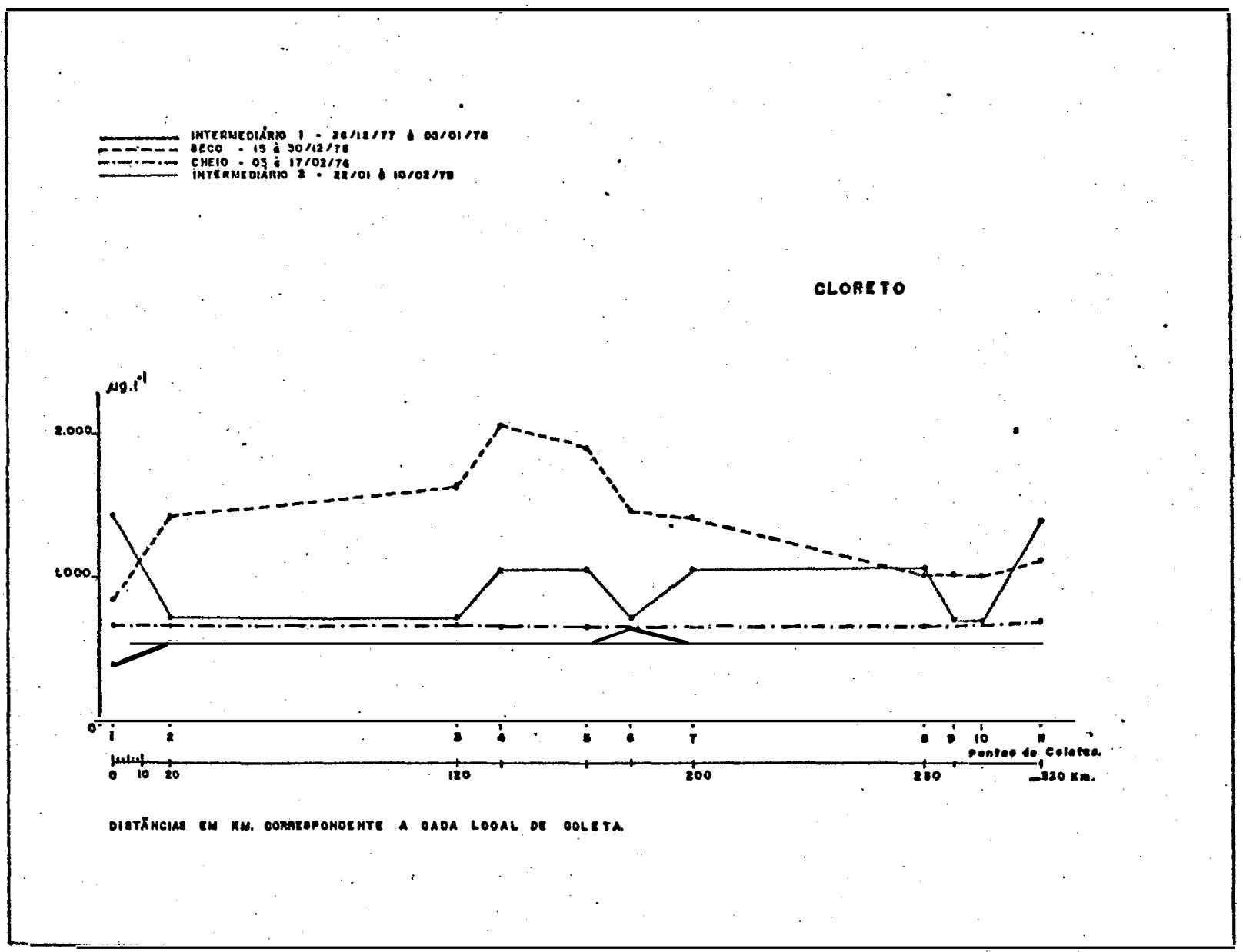

Figura 6 - Variação dos valores de Cloreto ( $1^{-}$) na Bacia do Parauari-Maués-Açu, nos períodos estudados. 
nas diferentes profundidades no ponto 11 , onde o rio forma uma baía com comportamento semelhante a'lago de rio".

Para uma explicação melhor do fenômeno observa do, haveria necessidade de maior número de amostras em diferentes profundidades, bem como um estudo mais detalhado das correntes.

\subsection{Sōdio e Potássio}

Nas Tabelas 7 e 8 e Figura 7 , encontramos os teores de sódio e potássio, para os períodos estudados. Pode mos observar, que os teores de potássio nas äguas da bacia Paruari-Maués Açū, são geralmente mais elevados que os de sódio. Só em alguns pontos desta bacia, verifica-se a predominância do sódio sobre o potássió. Porém, os dois elementos estão nitidamente relacionados. 0 valor da relação sódio/potássio é provavelmente devido às queimadas que ocorrem na região, bem como à decomposição natural da matéria vegetal.

$$
\text { BOYER (1971), para os solos de florestas em }
$$

Yangabi, no Congo Kinshasa, diz "a destruição e incineração das florestas equatorial forneceram ao solo 118 a $130 \mathrm{~kg} / \mathrm{ha}$ de $\mathrm{K}$ trocável, mais uma quatidade de pelo menos igual em $\mathrm{K}$ não trocável (vegetais não queimados ou insuficiente queimados), ou seja, um total de pelo menos $260 \mathrm{~kg} / \mathrm{ha}$ de $\mathrm{K}$ (metal) ou $310 \mathrm{~kg} / \mathrm{ha}$ 


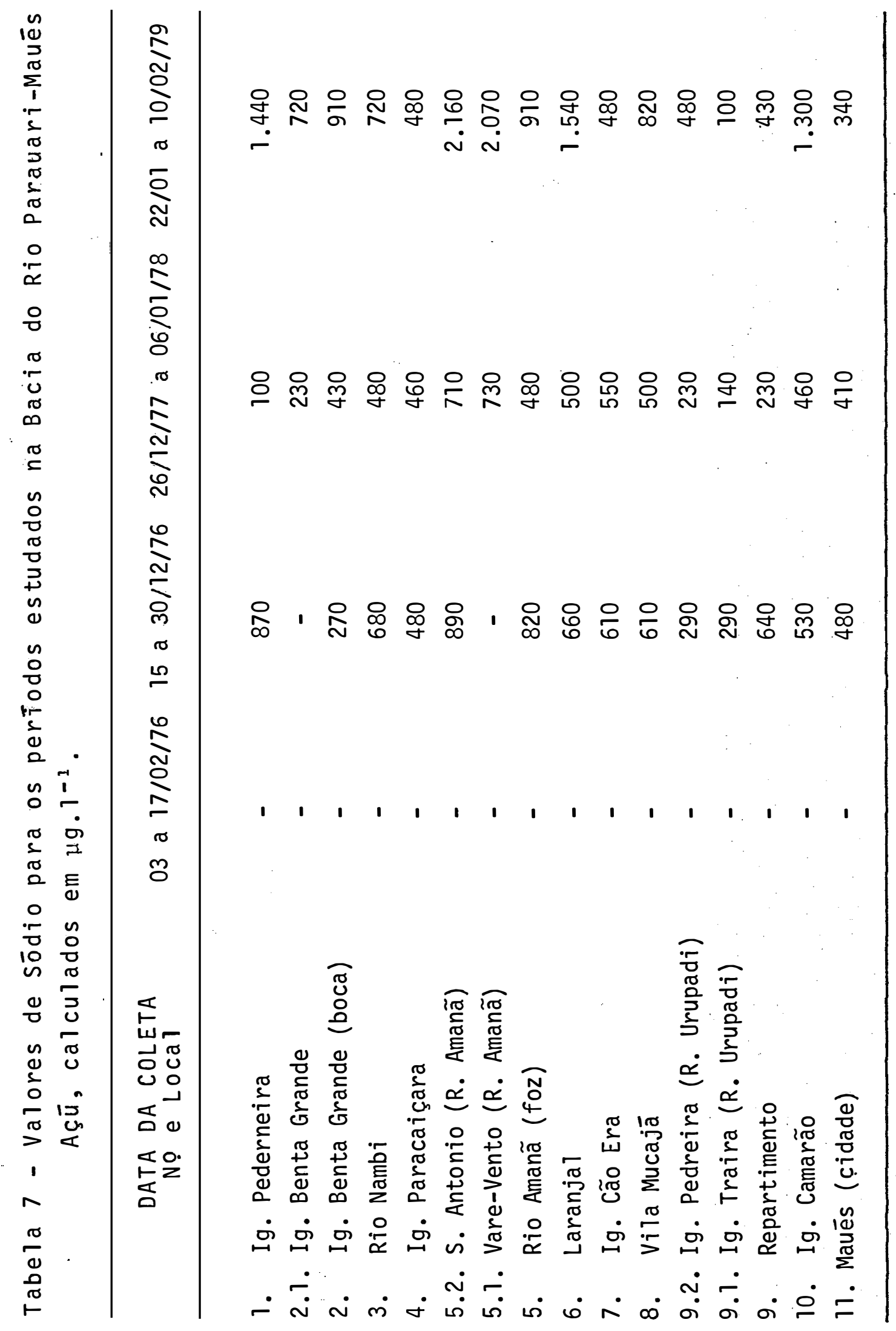




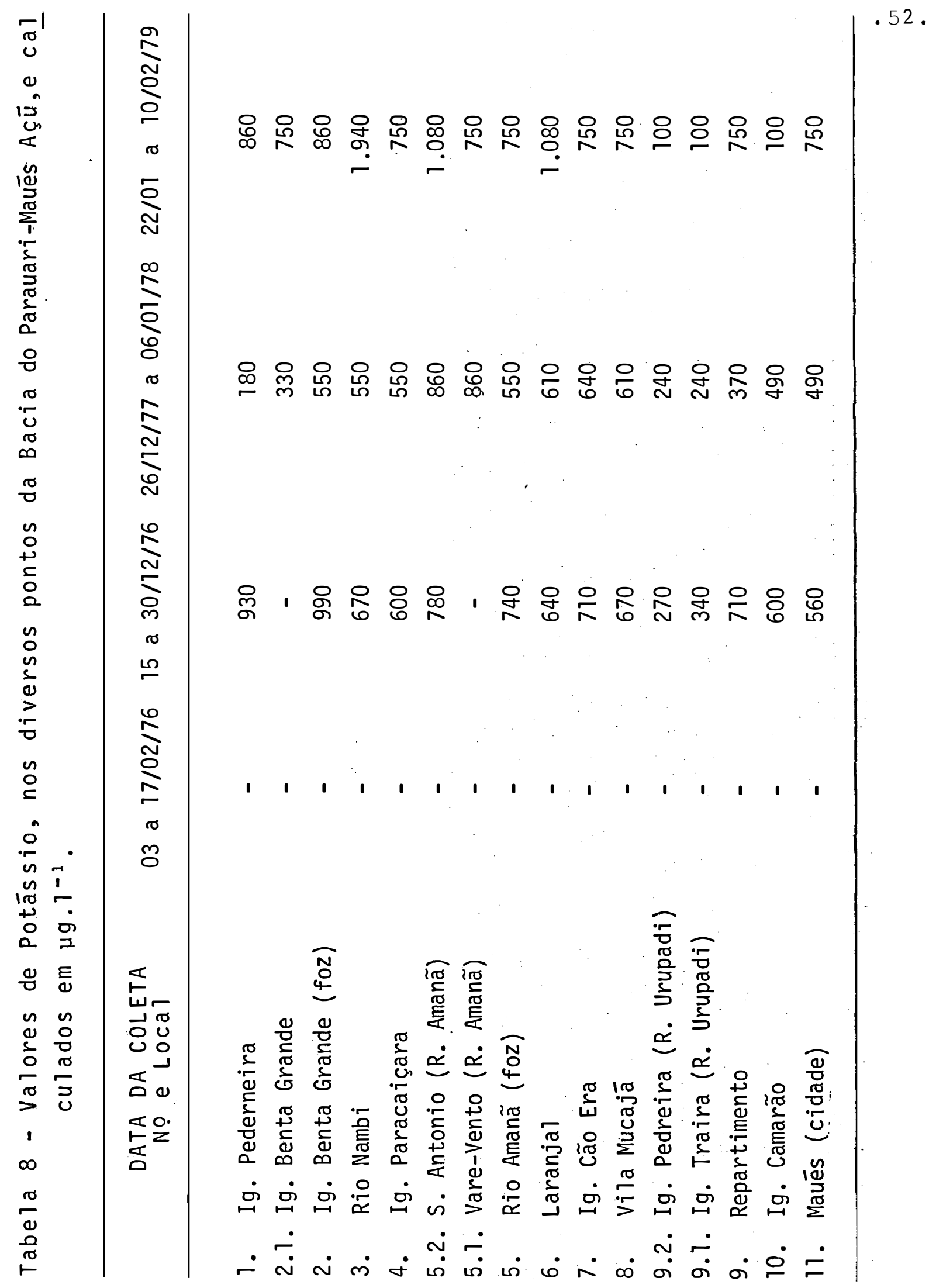




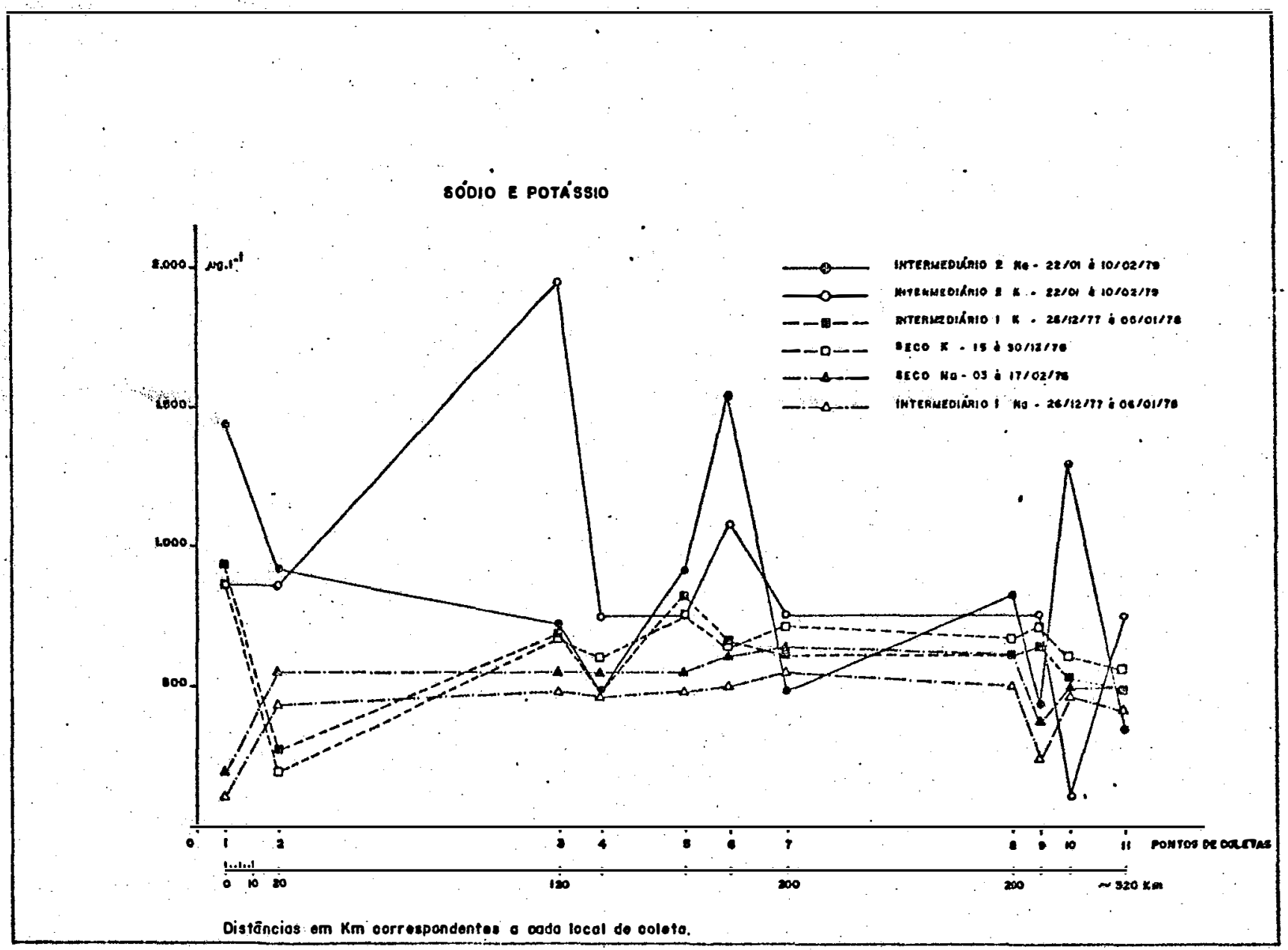

Figura 7 - Variação dos valores de Sódio e Potássio, nos períodos estudados da Bacia do rio Parauari-Maués-Açu. 
de $\mathrm{K}_{2} \mathrm{O}^{\prime \prime}$. Na região em estudo, não nos foi possível a obtenção de dados relativos às queimadas, para uma afirmativa mais segura, mas é possivel, que tais queimadas influenciem o meio ambiente em questão.

os altos teores de sódio no rio Amanã (pontos 5.2 e 5.1 em $22 / 01$ a $10 / 02 / 79)$, são de difícil explicação,des de que os teores de cloreto nos, mesmos locais e na mesma época não justificam a hipótese d $\mathfrak{C}^{\circ}$ ocorrência de salgema no curso do rio, única explicação plausível para essa anomalia.

Com a continuidade das chuvas as concentrações de sódio e potássio, tendem a aumentar nas águas da bacia,pro vavelmente devido ao arraste de substâncias, vindas das floresteas, principalmente o potássio, que é liberado durante as queimadas que ocorrem na época de menor pluviosidade e que são retidos no solo e lixiviados durante o início da estação chuvosa.

\subsection{Cobre, Zinco e Manganēs}

Nas Tabelas 9, 10 e 11 , são apresentados os teores de cobre, zinco e manganês, para os períodos estudados na bacia, do rio Parauari-Maués Açú, notando-se uma ligeira diferença entre os períodos de menor e maior volume d'água. 


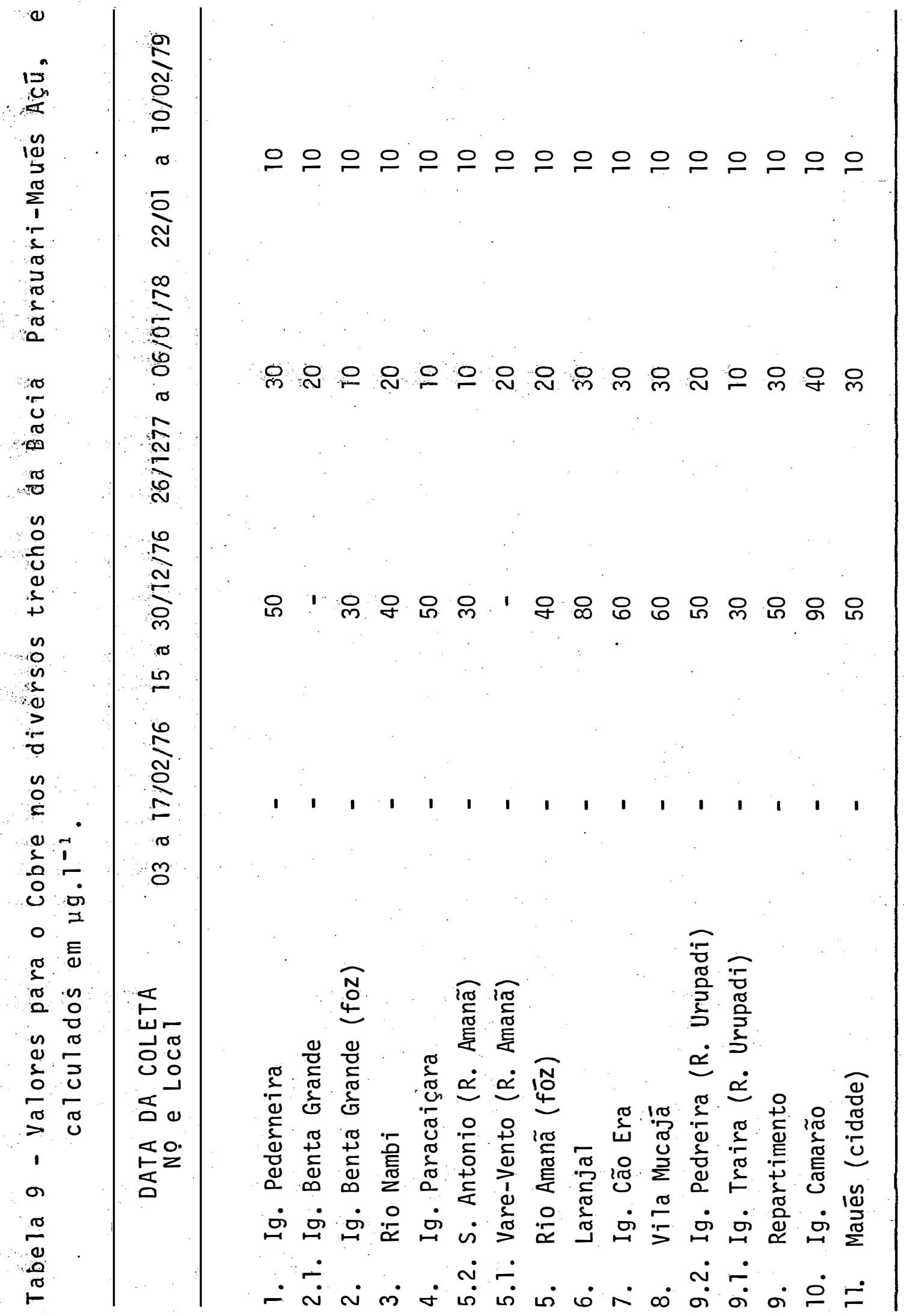




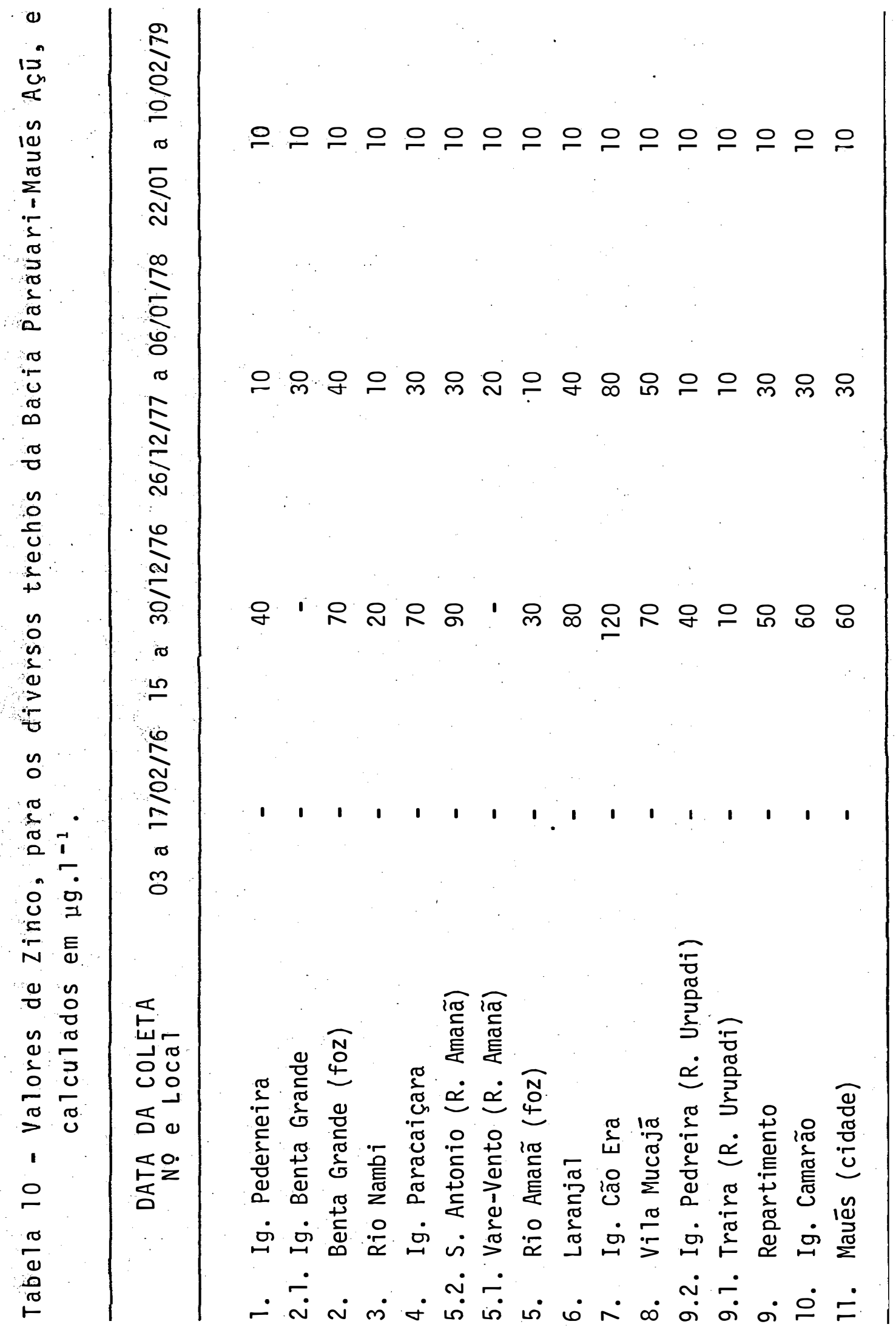




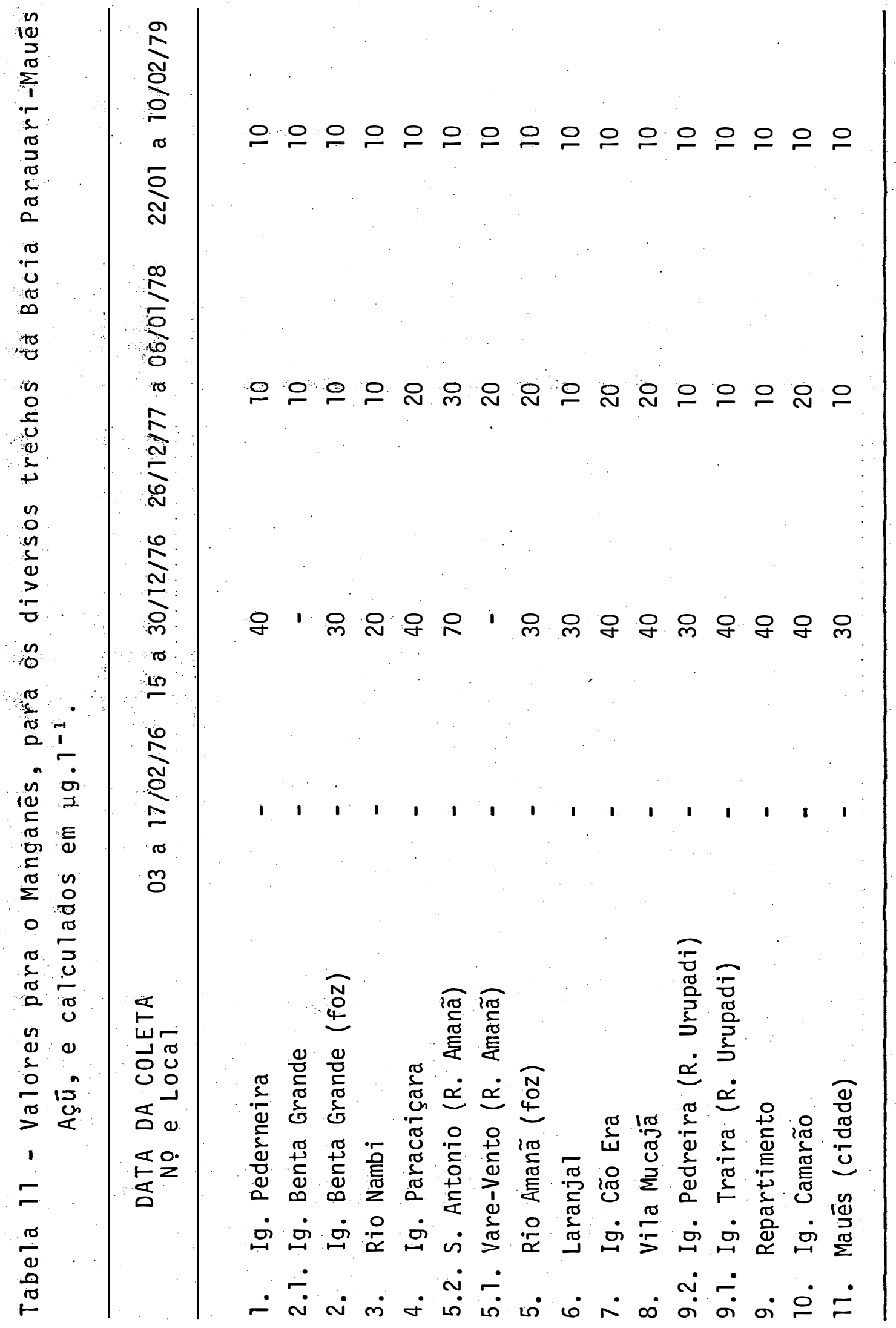


o igarapé do Cão Era (ponto 7) apresenta uma elevada concentração de zinco na época em que a bacia encontra-se com seunível de água $\left(120 \mu g \cdot 1^{-1}\right)$. Estudos posteriores, poderão elucidar qual a possível origem desse elemento, nesse trecho. Para os demais elementos e trechos estuda dos, não foram observados quaisquer anomalias estando esse íon dentro do estabelecido para as águas naturais. 
6. CONCLUSOEES

Os resultados obtidos na bacia do rio Parauari-Maués Açū, constantes nas Figuras e Tabelas, com também observações "in 1oco", levam às seguintes conclusões:

1. A composição química das àguas da bacia do rio Parauari-Maués Açū, é nitidamente influenciada pelas estações do ano, com variações sazonais, de acordo com as altera ções do nível das àguas e ocorrências climá ticas;

2. As a1terações no processo hidroquímico, são resultantes dos fenômenos acima referidos, como também, da localização do ponto de coleta e de outros fenômenos de natureza"físi ca, química e biológica;

3. Com relação à concentração dos diversos ele mentos, foram possiveis as seguintes conclusões: 
3.1. $\mathrm{pH}$

3.1.1. as āguas de precipitação afetam o pH dos rios ao diluirem as substâncias provenientes do so10 e subsolo da região;

3.1.2. os valores de $\mathrm{pH}$ sofrem modificações em função dos períodos de enchentes e vazante.

3.2. Cảlcio

3.2.1. no inverno, os teores de cá1cio são estáveis sofrendo variações entre a Vila Mucajāe a cidade de Maués próximo da foz;

3.2.2. no período seco, ocorre um aumento na concentração desse ele mento.

3.2.3. no período intermediário,ocorre uma elevação do teor de cálcio.

3.2.4: o teor de cálcio é praticamente constante em toda a bacia, com exceção de alguns pontos.

3.3. Magnésio

3.3.1. nos períodos estudados, nota-se 
que a concentração de magnésio, tende a uma ligeira diminuição à medida que se aproxima da foz;

3.3.2. as maiores concentrações ocorrem no período da cheia.

3.4 . Ferro

3.4.1. de um modo geral, os teores de ferro encontrados na bacia, estão dentro da faixa normal encontrada em outras regiões da Amazônia.

3.4.2. pequena variação sazonais ocor rem para teores desse elemento.

3.5. C1oreto

3.5.1. a concentração de cloreto nos períodos cheio e intermediário, são nitidamente constantes em toda a bacia.

3.5.2. no período seco, nota-se uma concentração mais elevada deste íon;

3.6. Sódio e Potássio 3.6.1. o potássio aparece em geral em 
concentrações maiores que o sōdio;

3.6 .2 . com exceção de uma época de amos tragem, houve uma nitida relação entre os teores de sódio e potássio;

3.7. os elementos cobre, manganês e zinco sao encōntrados em concentrações muito baixas e constantes ao longo da bacia, não sofrendo variações sensıveis aos diversos períodos estudados.

3.8. durante o período seco, as concentra ções dos diversos elementos tendem a aumentar enquanto, que com o início da cheia tendem a diminuir.

3.9. com a continuidade das chuvas no período intermediārio, as concentrações dos elementos, tendem a aumentar. 


\section{SUMMARY}

The chemical composition of the Parauari-Maués Aç $\bar{u}$ basin are studied through the determination of $\mathrm{pH}$, calcium, magnesium, iron, chloride, sodium, potassium, zinc, copper and manganese.

Four expedition were made and samples were collected in 16 different points of the main course.

- Chemical analysis of the river waters shows seasonal flutuations of the concentrations of the elements in the main river as well as in the main afluents like Nambi. river, Amanã river and Urupadi river. 
ABREU, S.F. 1973. Recursos minerais do Brasil, Vo1. I e II. Ed. Edgard Blucher - EUSP - SP.

ACKERMANN, F.L. 1962. Geologia e fisiografia da região Bragantina (Pará) INPA - Cadernos da Amazonia no 2.

ALBUQUERQUE, O.R. 1922. Reconhecimentos geológicos no vale do Amazonas. Bol. do M.A./Serv. Geol. e Mineralógico no 3. $84 \mathrm{p}$.

ALMEIDA, L.C. e A.F. SOUZA. 1972. Prospecção de solos no município de Maués-Açú. Informativo. IPA00c., $21 \mathrm{p}$.

ANON. 1972a. Die ionenfracht des Rio Negro, Staat Amazonas, Brasilien, Nach untersuchung von Dr. Herald Ungemach. Amazoniana, Kie1, 3(2):175-185.

ANON. 1972b. Regenwasseranalysen aus Zentralamazonién, ausgeführe in Manaus, Amazonas, Brasilian, von Dr. Herald Ungemach. Amazoniana, Kie1, 3(2):186-198. 
BOYER, J. 1971. Propriedades dos solos e fertilidade. Programa de Textos Didáticos XL. Universidade Federal da Bahia. $196 \mathrm{p}$.

BRINKMANN, W.L.F. e A. dos SANTOS. 1973. Natural waters in Amazonia VI. Soluble calcium properties. Acta Amazônia, $3(2): 33-40$.

DAEMON, R.F. e.C.J.A. CONTREIROS: 1971. Zoneamento palinoló gico da Bacia do Amazonas, Błém, Petrobrās-RENOR (Relatório Técnico Interno, 635-A) ÍN. DNPM-Projeto Radam-Folha SB-21. Tapajós: Levantamento de Recursos Naturais, Rio de Janeiro, 1975 . V.7 .

GESSNER, F. 1959. Hidrobotanik II. Berlim, Deutscher

Verlag der Wissenschafter.

IPEAAOC. 1971. So1os do Distrito Agropecuário da Suframa. Série Solos. Manaus, 1 (1):13-9.9.

LEVISON, A.A. 1974. Introduction to exploration Geochemistry-Departament of Geology University of Calgary, Alberta, Canada, Applied Publishing Ltda. $614 \mathrm{p}$.

MOURA, P. 1932. Reconhecimentos geológicos do Vale do Tapa jōs. M.A. Serv. Geol. e Mineralógico. Bol. ne 67. 53p.

MOURA, P. 1951. Geografia do Baixo Amazonas. Bo1. no 91. Serv. Geográfico e Mineralógico do M.A.

OLIVEIRA, A.I. e O.H. LEONARDOS. 1943. Geologia do Brasil. Rio de Janeiro, M.A. 
SAKAMOTO, T. 1957. Trabalhos sedimentalógicos geomorfológicos e pedogenéticos referentes à Amazônia. Belém, Missão FAO/UNESCO na Amazônia. SPVEA. 120 .

SANTOS, A. dos; S.R.B. BRINGEL, J.S.B. RIBEIRO. 1978. Hidroquímica da Amazônia Central I. Perdas de elementos nutritivos no ecossistema Campina Amazônica. Anais do 10 Simpó sio Nacional de Ecologia - 26 a 29 de setembro de 1978. Curitiba-Pr.

SIOLI, H. 1949. O Rio Cupari: Topografia e Hidrografia. Bol. Tec. Inst. Agron. do Norte (Belém) no $17.54 \mathrm{p}$.

SIOLI, H. 1950. Das Wasser in Amazonasgebiet. Fortschr., $26: 274-280$.

SIOLI, H. 1951a. Alguns resultados e problemas da limnologia Amazônica. Bol. Tec. Inst. Agron. do Norte (Bèém), $24: 2-44$.

SIOLI, H. 1951b. Estudo preliminar das relações eñtre a geologia e a limnologia da zona Bragantina. Bol. Tec. Inst. Agron. do Norte (Be1ém), 24:67-76.

SIOLI, H. 1956a. O Rio Arapiuns - Éstudo limnológico de um corpo d'água do terciário, plioceno das barreiras do Baixo Amazonas. Bol. Tec. Inst. Agron. do Norte (Belém), $32: 1-116$.

SIOLI, H. 1956b. As águas do alto Rio Negro. Bol. Tec. Inst. Agron. do Norte (Belém), 32:117-155.

SIOLI, H. 1957a. Valores de pH de águas Amazônias. Bol. do Museu Paraense Emilio Goeldi; Geologia, 1:1-37. 
SIOLI, H. 1957b. Die "Fruchtbarkeit" der Urwaldböden das brasilianischen Amazonasgebietes und ihre Bedeutung für eine zukünftige Natzung - Staden - Jahrbuch, 5:23-36.

SIOLI, H. 1957c. Beiträge zur regionalen Limnologia des Amazonasgebietes. IV. Limnologische Untersuchungen in der Region der Eisenbahnlińie Belém-Bragança (Zona Bragantina) im Staate Parā, Brasilien-Arch. f. Hydrobioz., $53: 161-222$.

SIOLI, H. 1965. Bemerkung zur Typologie amazonischer Flüss. Amazoniana, $1(1): 74-83$.

SIOLI, H. e H. KIINGE. 1962. Solos, tipos de vegetação e àgua na Amazônia. Bol. do Museu Paraense Emilio Goeldi, $1: 27-41$.

SIOLI, H. 1968a. Zue ökologie des Amazonas-Gebietes, p.137-170. In: Biogeography and Ecology in South America, Vo1. 1 .

SIOLI, H. 1968b. Hydrochemistry and Geology in the Brasilian Amazon region. Amazoniana, 1(3):267-277. 